\title{
Soil-Tree-Atmosphere Water Relations
}

\author{
Kemachandra Ranatunga \\ Bureau of Meteorology, Canberra \\ Australia
}

\section{Introduction}

A process model of the soil-tree-atmosphere continuum, which treats the plant physiology, eco-physiology and vegetation structures in detail, needs to describe the dynamics of the water flow within this continuum. The concept of a soil-plant-atmosphere continuum (SPAC) (Philip, 1966) was first described by Huber (1924). In such a continuum, the removal of water lowers the water potential in the leaves of the plant, and water moves in the direction of decreasing potential through a continuous liquid pathway extending from the soil through the plant to the leaves.

Water uptake, transpiration, radiative transfer and sensible heat exchange are the most important processes in a soil-tree-atmosphere continuum for water relations. Biophysical exchanges of radiative energy, sensible heat and water vapor in the canopy as well as soil water dynamics and soil and root resistances are physically and physiologically interrelated processes. In order to model biophysical exchanges between canopies and the atmosphere, it is necessary to integrate these processes. The root system and soil-water dynamics are very important in below-ground water transport. Therefore, the integration of soil and root resistances into the soil-tree-atmosphere continuum is necessary to estimate the water uptake by roots. In order to model transpiration radiative transfer, sensible heat exchange and scalar variations must also be understood. The processes of radiative transfer, transpiration, sensible heat exchange, diffusion and turbulent transfer in plant canopies are intrinsically mingled together. In order to predict the exchanges of energy and mass between the tree canopy and the atmosphere in a mechanistic manner it is necessary to couple these processes directly. This means that the soil-vegetation-atmosphere transfer processes for water relations are inevitably complex.

Studies of above- and below-ground processes have been conducted by meteorologists and plant ecologists for a long time (Monteith, 1975; Gates, 1980; Grace, 1983; Landsberg and McMurtrie, 1984; Landsberg (1986). The integrated modeling process of the soil-treeatmospheric continuum for water relations is essentially a synthesis of available physical theories describing water loss from leaves and the movement of water from soil to roots and through plants, is to examine the effects of soil and tree water status, radiative transfer in the canopy and other weather parameters on transpiration with the ultimate aim of predicting tree water uptake. A variety of different models has been developed for each of these processes. Theoretical basis and reviews of these models can be found in Ross (1981), Goel (1988), Myneni et al. (1989), and Myneni and Ross (1990). These developments have created 
a great diversity of models of soil-tree-atmosphere transfers in which the processes are partly or fully integrated. However, these models all share a common characteristic: they infer canopy functions from leaf observations. Based on how the inference is achieved, models of soil-tree-atmosphere transfers can be divided into four groups: the big-leaf models, direct scaling models, multi-layer canopy models and multi-layer soil-canopy models. Multi-layer models can be further divided into two types: incomplete multi-layer models and complete multi-layer models. This chapter describes these methods and presents the background of the soil-tree-atmospheric water transfer.

To overcome shortcomings of previous multi-layer models, accurate descriptions of basic biophysical processes are given first priority in the modeling process. Complex models, whose wide-range application is often hampered by the lack of specific data, should have their processes simplified in order to be accommodated into spatial frameworks where appropriate. Biophysical processes within simple models should consider new data sources and understanding to gain more accurate predictions (Ranatunga et al., 2008). Simplicity can be pursued only when the reality of basic biophysical processes is not compromised. The process of water movement through the soil-plant-atmosphere continuum has been widely and sucessfully used (Molz, 1981; Jarvis et al., 1981; Boyer, 1985; Eckersten, 1991; Ranatunga and Murty, 1992; Nobel and Alm, 1993; Cienciala et al., 1994; Friend, 1995; Williams et al., 1996). The integrated modeling process is designed to cover both below- and above-ground processes, which can be combined through a methodology that links the soil-water status with the atmospheric weather conditions through canopy exchangeable water storages and estimated tree water uptake by roots and water loss by transpiration.

\section{Below-ground processes}

Water uptake from the soil by roots is determined by soil water content and other related soil physical properties, the root architecture system and soil and root resistances to water flow as well as demand from the canopy. As more fine-scale detailed data on the physiology of water absorption become available, the integration of this information into a quantitative framework from the root to the soil layer level can be established by coupling of the soil water dynamics and root architecture. Finally, water flow resistance from soil to root as well as for radial and axial resistances in the roots can be calculated for the entire root system.

The amount of water that a tree can remove from the soil depends on the volume of soil exploited by the root system of the tree (Landsberg and McMurtrie, 1984). Water absorption by roots from the soil is determined by three main factors:

1. soil properties such as soil water content, hydraulic conductivity and water potential,

2. root-system architecture as a network of absorbing organs, and

3. the absorption capacity of roots is dependent on water flow resistances, i.e., the soil and root resistances.

Although the water movement in soil is well represented by microscopic or macroscopic approaches, a detailed description of the root system is lacking (Molz, 1981). Water movement through plant roots has been theoretically analyzed by Landsberg and Fowkes (1978) who derived an analytical solution for a single root with a constant hydraulic resistance. Alm et al. (1992) extended Landsberg and Fowkes' approach to a case of 
variable resistance along the root by separating roots into segments, each with homogeneous resistance. With recent advances, the physiological characteristics of water uptake by roots such as radial and axial resistances can now be examined at the centimeter scale (North and Nobel, 1995). Simulation models for the below-ground tree are needed because of the difficulty in observing and quantifying the architecture of roots, the soil-water dynamics and the soil and root resistances to water flow. By coupling soil water dynamics and root architecture along with soil and root hydraulic resistances, the process of water transport from the soil to the roots and through the roots can be described. The below-ground processes and their interactions in relation to water movement are illustrated in Fig.1.

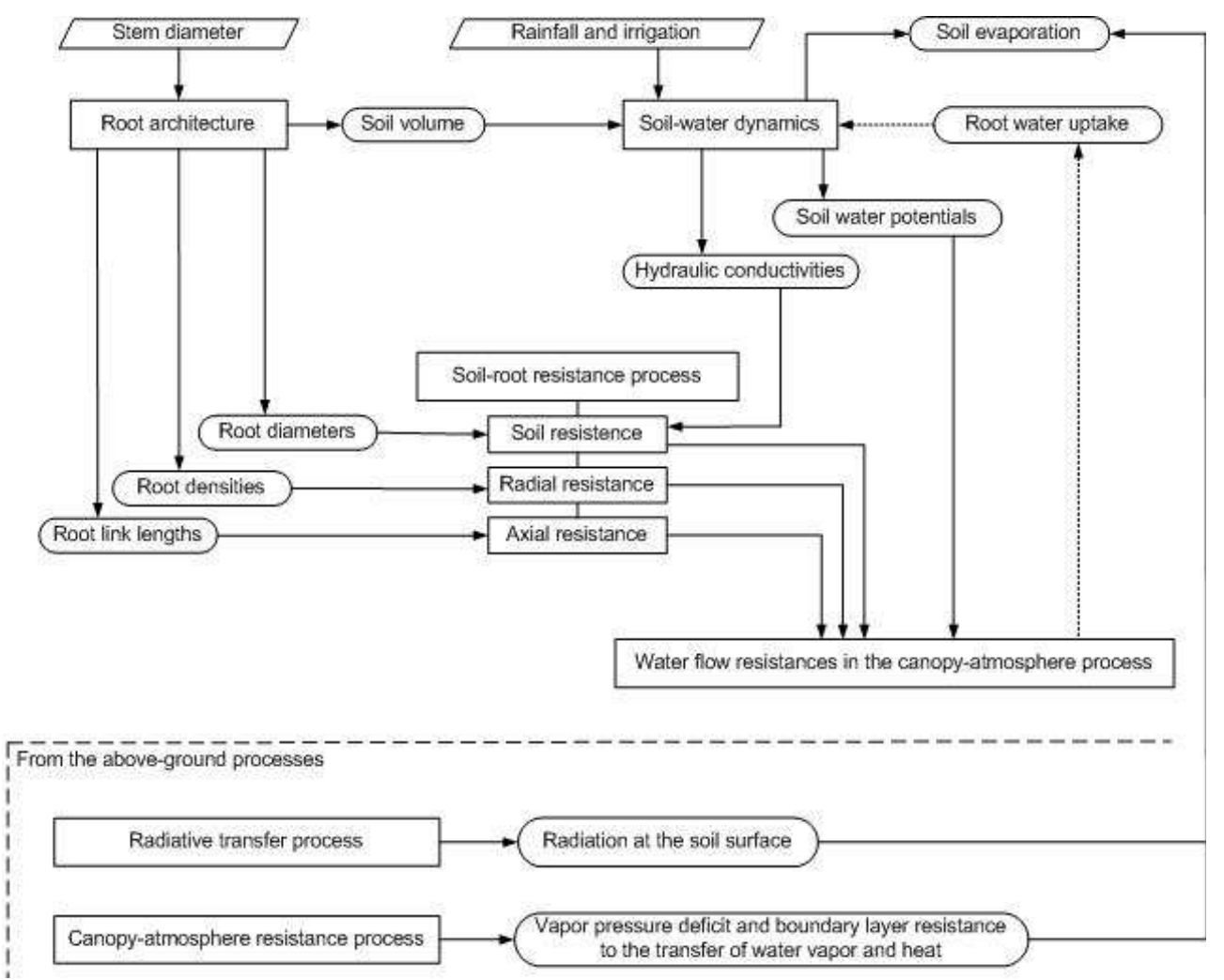

Fig. 1. A concise structural diagram of the below-ground processes and their interactions

\subsection{Modelling soil water dynamics}

Although soil-water fluxes are difficult to measure, the relative capabilities of existing models and the credibility of their results are still an important concern because soil water dynamics is sometimes inadequately represented in models of the soil-plant-atmospherewater interactions and processes (Clemente et al., 1994). Analytical solutions to the soilwater flow equation (Richards' equation (Richards, 1931)) are not possible for dynamic field 
situations (Zeng and, Decker, 2009) and most efforts have been concentrated on seeking numerical solutions (e.g. Feddes et al., 1978; Broadbridge and White, 1988; Ranatunga and Murty, 1992).

A numerical solution for the unsaturated vertical soil water flow with varying water supply (irrigation and rainfall) is typically used to estimate soil water content in a verticallystructured soil profile (Ranatunga and Murty, 1992). This numerical solution also gives an implicit finite difference solution to the soil water flow equation. The assumption of only one-dimensional vertical flow is quite accurate for agricultural rooting depths (Bresler, 1991). Soil evaporation can be based on a modified version of Penman-Monteith equation (Raupach, 1991) and vapor-flow flux (within the soil profile) is neglected except at the top layer of the soil. To examine the water flow in soils, a volumetric sink term may be added to the classic Richard's flow equation for one-dimensional flow under gravity (Feddes et al., 1978).

At the soil-air interface the soil can lose water to the atmosphere by evaporation of soil water where the potential rate of soil evaporation depends only on atmospheric conditions. During evaporation the requirement is that (Feddes et al., 1978):

$$
\psi(\mathrm{z}, \mathrm{t}) \geq \psi_{i} ; \quad \mathrm{t}>0, \mathrm{z}=0
$$

where $\psi$ is the pressure head and $\psi_{1}$ is the minimum pressure head allowed under air-dry conditions. Typically, $\psi_{1}$ is estimated from the mean temperature and relative humidity of the surrounding air, and if it is assumed that the pressure at the soil surface is in equilibrium with the atmosphere, then, $\Psi_{1}$ can be derived from the following relationship (Feddes et al., 1974):

$$
\psi_{l}=\frac{R T}{M g} \operatorname{In}(R h)
$$

where $R$ is the universal gas constant $\left(8.314 \mathrm{~J} \mathrm{~mol}^{-1} \mathrm{~K}^{-1}\right), T$ is the absolute temperature $(\mathrm{K}), g$ is the acceleration of gravity $\left(9.81 \mathrm{~m} \mathrm{~s}^{-2}\right), M$ is the molecular weight of water $\left(0.018 \mathrm{~kg} \mathrm{~mol}^{-1}\right)$ and $R h$ is the relative humidity as a fraction. The simplest option and one which is often used in modeling soil-water flow, is to neglect vapor flow except at the soil surface (Campbell, 1985). Janz and Stonier (1995) incorporated the evaporation rate into the sink term of the top soil layer and were able to make reasonable predictions of soil water dynamics.

The soil water deficit is the amount of water needed to bring the soil moisture content back to field capacity, which is the amount of water the soil can hold against gravity. The soil water deficit is calculated by subtracting the total water content of the soil layer from the water content at the field capacity of the root zone. In standard models, rainfall and the amount of irrigation applied are assumed to be equally distributed among the soil layers, and adjusted by adding to the water content of the soil layer. The numerical procedure gives the soil-water content in vertically structured soil layers.

The Penman-Monteith equation provides good predictions of evaporation of forest surfaces (Saugier, 1996). It uses a modification of the form employed by Raupach (1991) as applied by Walker and Langridge (1996): 


$$
F_{E}=\left(\frac{\varepsilon \text { Rnet }_{\text {soil }}+\frac{\rho \lambda V P D}{R a_{\text {soil }}}}{\varepsilon+1+\frac{R R_{s s}}{R a_{\text {soil }}}}\right) \frac{1}{\lambda}
$$

where $F_{E}$ is the evaporation rate $\left(\mathrm{kg} \mathrm{m}^{-2} \mathrm{~h}^{-1}\right)$, Rnet soil is the net radiation at the soil surface (MJ $\left.\mathrm{m}^{-2} \mathrm{~h}^{-1}\right), \rho$ is the air density $\left(\mathrm{kg} \mathrm{m}^{-3}\right), \varepsilon$ is the dimensionless slope of the saturation specific humidity, $\lambda$ is the latent heat of vaporization $\left(\mathrm{MJ} \mathrm{kg}^{-1}\right), V P D$ is the vapor pressure deficit, $R_{a}$ soil is the boundary-layer resistance to the transfer of water vapor and heat (between the soil surface and bottom of the canopy) $\left(\mathrm{s} \mathrm{m}^{-1}\right)$ and $R_{s s}$ is soil surface resistance $\left(\mathrm{s} \mathrm{m}^{-1}\right) . R_{s s}$ that restricts the transfer of water from the soil surface by evaporation can be calculated as (Walker and Langridge, 1996):

$$
R_{S S}=R_{S S(\min )} f(S W C)^{-1}
$$

where $R_{s s(\min )}$ is the minimum value of the soil-surface resistance under optimal conditions and $S W C$ is the soil water content in the topmost layer.

\subsection{Modelling root architecture}

The architecture and space filling properties of the below-surface tree organs are necessary for a mechanistic understanding of water uptake. Pioneering work in numerical simulations of root systems was done by Lungley (1973). Based on theoretical study, Claasen and Barber (1974) assumed uniform root distributions. Rengel (1993) pointed out that the assumption of uniformity of root distribution used in models based on Claasen and Barber (1974) is an oversimplification, since the way roots fill the soil matrix is important for nutrient and water acquisition (Sattelmacher et al., 1990). Fitter et al. (1991) also described a simulation model of root growth that simulated the development of root systems varying in several important architectural features including root link length. Root link length refers to a distance between two branching points in the root (Bernston, 1994).

Some attempts have been made to relate root biomass to stem diameter at a standardised height (Santantonio et al., 1977; Brown et al., 1989), but such relationships probably depend on tree species and site. Soumar et al. (1994) found in a study on Sclerocaryea birrea, that the root diameter at $1 \mathrm{~m}$ from the stem base is an appropriate parameter for predicting horizontal root distribution. However, relating the size of the root system to proximal root diameter may be more successful than relating it to stem diameter (Van Noordwijk et al., 1994).

Fitter et al. (1991) have suggested that it is not possible to derive a simple analytical relationship between root system architecture and water and resource acquisition due to the complexity of the spatial arrangement of the roots within the soil. Fractal geometry is a system of geometry that is more suited to the description of many biological objects than is standard Euclidean geometry (Mandelbrot, 1983). Fractal geometry provides useful perspectives on root branching patterns (Shibusawa, 1994; Van Noordwijk et al., 1994) and it is reasonable to accept that fractals may provide quantitative summaries and functional insights into root architecture (Bernston et al., 1995).

The branching pattern has been identified as an important characteristic of root systems that strongly influences patterns of foraging within the soil matrix (Fitter, 1987; Hetrick, 1988) 
and nutrient and water acquisition (Robinson et al., 1991). There have been a number of attempts to produce architectural classifications of root systems (Weaver, 1968; Krasilnikov, 1968) but none have been particularly successful, partly because of the great variability of root systems. However, following Coupland and Johnson (1965), Van Noordwijk et al., 1994 identified two major classes of fractal branching patterns, i.e., herringbone and dichosyntomous. Most monocots follow the herringbone root branching pattern comprising of a main root and laterals whereas most dicots have a dicho-syntomous branching pattern that spawns the parent branch into two daughter branches (Zamir, 2001).

The most important and easily-measurable parameter for root modelling is the proximal root diameter. The relationship between proximal diameter and the total root length of all root links obviously depends on the root branching pattern. Leonardo da Vinci (quoted by Mandelbrot, 1983 and the quoted by Van Noordwijk et al., 1994) claimed that the cross sectional area of the main stem is equal to the sum of the cross sectional areas of tree branches. A relationship can be sought between the root diameter at the stem base, and functionally important root parameters (Van Noordwijk and Brouwer, 1995) such as the total root length. This approach, known as a pipestem model (Shinozaki et al., 1964) states that each unit of foliage requires a unit pipe of wood to connect it to the root system, and has been used by Van Noordwijk et al. (1994) to understand the geometry of root branching in plants, giving the relation between proximal diameter of the root base and the diameter of the divided axes:

$$
\frac{\pi D o^{2}}{4}=\frac{\alpha \pi}{4} \sum_{j=1}^{N k} D i_{j}^{2}
$$

where $D_{\mathrm{o}}$ is proximal diameter at the root base $(\mathrm{m}), D_{i}$ is diameter of the divided axes in the link $i(\mathrm{~m})$, a is proportionality of cross sectional area before a branching event and the sum of the cross sectional areas after branching and $N k$ is the number of branch roots per branching event. In many previous studies (summarized by Van Noordwijk et al., 1994) on root architecture, root link length was assumed to be a constant for a whole root system or a part of root system. A recursive programming procedure can be adopted for divisions of root branching. The number of branching steps in each lateral branch can also be in the recursive programme (Van Noordwijk et al., 1994).

The length of the root axis $(L)$, which is an important parameter for understanding how the root system fills the soil matrix can then be calculated as:

$$
L=n L_{m}
$$

where $L_{m}$ is the mean length of the root link in the main or lateral axis and $\mathrm{n}$ is the number of root segments in the root system. With an estimated $L_{m}$ value for each root link, it is possible to calculate the length of the root axis. Values of $L$ decrease with increasing diameter and the longest roots occur in the small diameter classes (Kodrik, 1995).

The soil volume explored by roots in each soil layer $\left(V t_{i}\right)$ can be determined (Pregitxer et al, 1997):

$$
V t=\pi L_{R Z}^{2} z
$$


where $L_{R Z i}$ is the radius of the rooting zone in the soil layer $i$ and $\mathrm{z}$ is the depth of the soil layer. The architecture of a root system can be dissected into a number of measurable variables of which the most important is root density $(D t)$ which is defined as the root length per unit volume and $D t$ is calculated as (Tardieu, 1988):

$$
D t=\frac{\left(\sum_{n=0}^{n_{m}} L_{m_{n}}+\sum_{n=0}^{n_{l}} L_{l_{n}}\right)}{V t}
$$

where $n_{m}$ and $n_{l}$ are the number of branching events in the main axis and lateral axes respectively, $L_{m n}$ is the length of the root link in the main axis and $L_{l n}$ is the length of root links in lateral axes.

\subsection{Water flow resistances in the soil-root system}

In the soil-plant-atmosphere continuum, water flow is driven through a series of hydraulic resistances that can be identified as soil resistance, root radial resistance, and root axial resistance pertaining to the pathways of conduction through xylem vessels, and stomatal resistance with a boundary layer adjustment to the leaf surface.

Root resistance is partitioned into radial and longitudinal (axial) components and the relative importance of these has been stressed (Passioura, 1984; St Aubin et al., 1986). However, reasonable quantitative data of axial resistance $\left(R_{l}\right)$ and radial resistance $\left(R_{r}\right)$ is rare, even though these quantities are a prerequisite for the proper modeling of water flows through roots. The procedure for resistance calculations is mechanistically more appropriate than steady-state models because it includes the effect of the soil-water influence on resistance.

Assuming that the soil hydraulic conductivity $\left(K_{s}\right)$ is constant within the particular soil layer, the soil resistance associated with the root $R_{s}\left(\mathrm{~kg}^{-1} \mathrm{~m}^{4} \mathrm{~s}^{-1}\right)$ was developed by Moldrup et al. (1992). Water uptake by roots in wet soil is generally determined by the root hydraulic resistance, which is composed of the radial resistance $\left(R_{r}\right)$ from root surface to xylem, and axial resistance $\left(R_{l}\right)$ along the xylem (Landsberg and Fowkes, 1978; Passioura, 1988). The sum of $R_{r}$ and $R_{l}$ are often called the plant resistance that is found to be independent of the water potential gradient (Abdul-Jabbar et al., 1984) and transpiration rate (Neumann et al., 1974). Therefore, regardless of changes in soil and plant water status with time, $R_{r}$ and $R_{l}$ are normally assumed to be constants (Frensch and Steudle, 1989). .

Assuming that the membranes of cells to be crossed before water reaches the xylem form concentric cylinders, it can be easily shown that radial resistances would be related to each other by (Steudle and Brinnkman, 1989):

$$
R_{r}=R_{\text {cell }} \sum_{k=1}^{n^{c}} \frac{r^{r}}{r_{k}^{c}}
$$

where $R_{\mathrm{r}}$ is radial resistance $\left(\mathrm{kg}^{-1} \mathrm{~m}^{2} \mathrm{~s}^{-1}\right), R_{\text {cell }}$ is cell resistance $\left(\mathrm{kg}^{-1} \mathrm{~m}^{2} \mathrm{~s}^{-1}\right), r_{\mathrm{k}}$ is the radius of the $k$ cell layers to be crossed by water, $n^{\mathrm{c}}$ is the average number of cells to be crossed before water reaches the xylem and $r^{r}$ is the radius of the root. Thornley and Johnson (1990) 
explained how the resistance from root surface to the plant vary with the number of roots per unit area in a vertically-structured soil profile.

Melchior and Steudle (1993) stated that $R_{1}$ can contribute substantially to the overall hydraulic resistance or even can be the limiting component. Passioura (1972), Newman (1976) and Meyer and Ritchie (1980) used a modified Poiseuille-Hagen equation to calculate $R_{l}$ from root xylem dimensions:

$$
R_{l}=\frac{4 \eta L}{\rho_{w}^{2} \pi \sum_{i=1}^{n^{v}} r_{i}^{4}}
$$

where $R_{\mathrm{l}}$ is axial resistance $\left(\mathrm{kg}^{-1} \mathrm{~m}^{4} \mathrm{~s}^{-1}\right)$ associated with the root link, $r_{i}$ is mean effective diameter of the xylem vessels $(\mathrm{m}), \eta$ is the viscosity of water $\left(0.001002 \mathrm{~kg} \mathrm{~m}^{-1} \mathrm{~s}^{-1}\right)^{1}, L$ is the length of the xylem vessel $(\mathrm{m}), n^{\mathrm{v}}$ is average number of conducting xylem vessels in the root and $\rho_{\mathrm{w}}$ is the density of water $\left(\mathrm{kg} \mathrm{m}^{-3}\right)$.

\section{Above-ground processes}

Canopy processes such as the leaf-energy balance and transpiration are relatively well understood. However, a sound understanding of how these processes integrate spatially and temporally within trees remains elusive. One approach to tackle this problem is the use of models that allow scaling of canopy processes at the leaf level to the whole canopy (Jarvis et al., 1985; Running and Coughlan, 1988; McMurtrie, 1993; Jarvis, 1995). Both aggregated (e.g. 'big-leaf') and distributed (e.g. multi-layer or three-dimensional) approaches are commonly applied in modeling canopy processes. There are costs and benefits to both (Raupach and Finnigan, 1988): Simulations with distributed modeling approaches require assumptions about the distribution of key parameters in space (and time), but allow model parameterization using fine-scale data. Aggregation avoids the need for spatial details by building the effects of non-linearities into the model parameters. These parameters must be estimated directly from coarse-scale data (e.g. canopy rather than leaf-level data).

Tree canopy structure is a complex and dynamic outcome of the evolutionary and ecological interactions and feedbacks between vegetation and environment. Since the transpiration from a single tree is a non-linear function of absorbed solar radiation and other related environmental variables (e.g. temperature, humidity, and wind speed), it is necessary to be able to simulate the radiation regime and other related environmental variables within the canopy and before, the transpiration rate can be adequately calculated. Therefore, the aboveground modeling presented in most of the literature (Myneni and Impens, 1985; Wang and Jarvis, 1990; Whitehead et al., 1990; Ryel et al., 1993) is largely based on hypothesized spatial independence structures from which the canopy is made. It, therefore, precludes an aggregated approach.

Three-dimensional models of the radiative transfer and canopy architecture represent a compromise between the simplicity of the uniform canopy models and the complexity of

\footnotetext{
${ }^{1}$ The temperature dependence of the viscosity of water is not taken into account. The temperature of water is assumed to be $20^{\circ} \mathrm{C}$.
} 
architectural models. A fairly straightforward method can be introduced to formulate the three-dimensional canopy in terms of the amount and spatial distribution of leaf area within the crown. Thus, each vertical canopy layer has geometrically-defined sub-canopies, assuming a vertically heterogeneous canopy consisting of horizontally homogeneous layers.

The radiation, stomatal and leaf boundary-layer resistances, micro-environmental variables and finally the energy balance vary within the canopy. Consequently, the vertical and horizontal variations within the model become apparent. Far-field variation of wind speed and air temperature can normally be simulated with depth outside the canopy, but a uniform profile of vapor pressure outside the canopy is normally assumed (these assumptions are discussed in detail later).

The prediction of the vertical distributions of micrometeorological variables is regarded as a necessary step in the prediction of sub-canopy level fluxes. The adoption of integrated stomatal resistance has received theoretical (Finnigan and Raupach, 1987; Paw U and Meyers, 1989; Kelliher et al., 1994; Raupach, 1995; Leuning et al., 1995) and experimental (Baldocchi et al., 1987) criticism over the years. As the radiation intercepted and scalar concentrations can be calculated in each sub-canopy within the crown, it is possible to estimate the stomatal resistances individually for each sub-canopy and hence, avoid the integration of the stomatal resistance for the entire canopy. Similarly, the boundary layer resistance can be calculated for each sub-canopy and it is not required to integrate over the total leaf area of the canopy.

The above-ground canopy processes would normally include;

- the canopy architecture and leaf area - a three-dimensional analysis to estimate the beam path length of each and every volume of the sub-canopies within a paraboloidshaped-canopy, and to estimate the vertical leaf-area distribution using a Weibull statistical pattern,

- the solar position and day length - a methodology to calculate the zenith and azimuth angles of the sun on an hourly basis and hence the day length,

- the radiative transfer through the canopy - a comprehensive methodology for radiative transfer (short-wave direct, long-wave, and diffuse) through the crown,

- the energy-balance process - an application of the energy balance equation to each volume of the sub-canopies in order to estimate leaf temperature,

- the scalar variation - to estimate wind speed, air temperature, relative humidity and solar radiation, and

- the canopy-atmosphere processes for resistance calculations - to estimate the stomatal and leaf boundary-layer resistances.

These canopy processes are discussed in detail in the following sections. The above-ground processes and their interactions in relation to water movement are given in Fig.2.

\subsection{Crown architecture and leaf area estimates}

The geometric form of the crown is one of the main factors that govern the productive potential of vegetation (Jahnke and Lawrence, 1965). The shape of the crown is strongly correlated with the volume and height of the stand. Biging and Dobbertin (1995) found that the geometric space occupied by the crown is highly correlated with growth. This raises the question, therefore, whether canopy form can be readily quantified. 


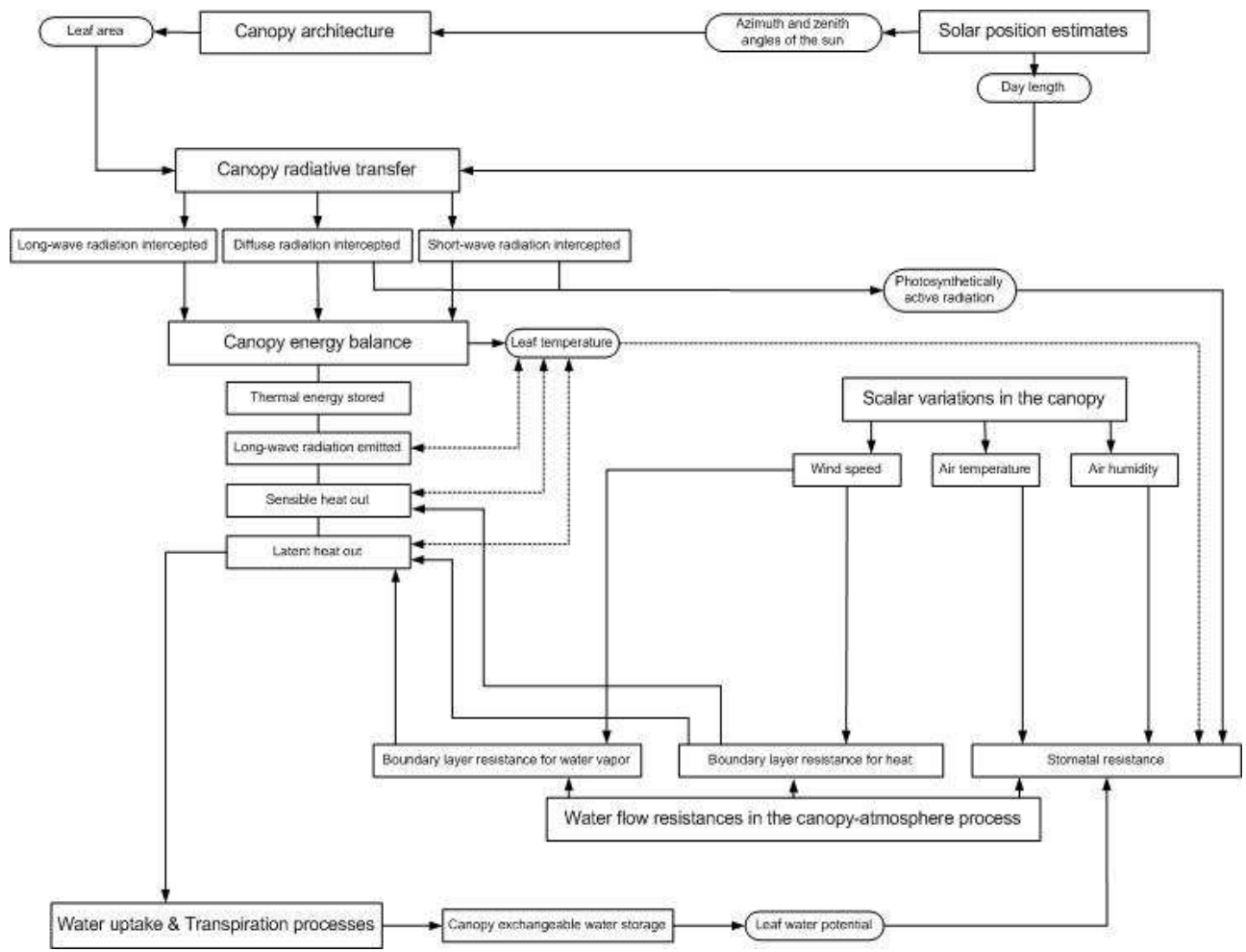

Fig. 2. A concise structural diagram of the above-ground processes and their interactions

A number of simplifying assumptions were usually made about canopy architecture to model light penetration and to assess canopy leaf area. The most elementary canopy description applied in mechanistic models is the stand-oriented approach; the canopy is assumed horizontally continuous and radiation absorption is calculated per hectare. This approach is sufficient when simulating regularly constructed, mono-species stands with closed canopies (Mohren, 1987; Nikinmaa, 1992; Bossel and Krieger, 1994). However, statistical models describing horizontally homogeneous stands are not applicable in stands where the foliage is grouped into individual tree crowns (Oker-Blom, 1986) and tree crowns display a great variety of aerial structure, which, in response to the environment, show different solutions to the problems of resource capture. As all trees depend on the radiation energy, it is evident that the vegetation structure of trees is regulated by the spatial and temporal variation of irradiance.

Models with one-dimensional canopy layers have been proposed by many authors following Monsi and Saeki (1953). Models of homogeneous continuous canopies of forests or crops have been used to provide insight into the role of specific characteristics such as leaf angle and leaf area index or vertical distribution of leaf characteristics such as leaf mass per unit area or volume (Gutschick and Weigel, 1988). Discontinuous canopies such as those formed by trees need more dimensions to analyze the vertical and horizontal variations of the radiation distribution. For individual trees, qualitative models of branching have been 
used to describe the development of form (Halle et al., 1978), but these have had limited ecological applicability in understanding how specific architectures influence the resource capture.

Unfortunately, quantifying crown geometry is difficult because the profiles are usually irregular and simple geometric representations may not be adequate (Biging and Dobbertin, 1995). The occurrence of vertical layering or stratification in a tree canopy has been a matter of considerable attention, not least because of inconsistent definitions and methodology (Bourgeron, 1983). Richards (1983) referred to the stratification of leaf mass and of individual tree heights for which the evidence is weak. Stratification of species refers to the vertical aggregation of average mature heights of species. Extensive quantitative documentation of this phenomenon is also lacking, but there is some support for its existence (Pukkala et al., 1991).

In systems with discontinuous canopies, a more detailed canopy description is necessary, since the diurnal variation of radiation availability and interception are much larger than in closed forests (Palmer, 1977). Array models have been developed that account for horizontal differences (Palmer, 1977), and these canopies were often modeled as a series of onedimensional layers that are horizontally homogeneous. But because individual crowns are not distinguished, their application is limited to canopies which can be defined in simple geometrical terms.

Two dimensional models have been used to explore how branch angle and branch length influence leaf overlap and hence the efficiency of irradiance capture (Fisher, 1992). Two dimensional models for parallel rows have been described for rectangular (Goudriaan, 1977; Sinoquet and Bonhomme, 1992), elliptical (Charles-Edwards and Thorpe, 1976) and triangular (Jackson and Palmer, 1979) cross-sections. These models are adequate for infinite hedgerows. They consider the interception of light from only a single direction, whereas, in reality, diffuse radiation comes from many directions and the direction of the solar beam changes during the day (Bristow et al., 1985). Modeling an isolated tree presents more difficulty than uniform canopies or row crops where it is possible to reduce the dimension of the problem to a single coordinate. For row crops it is still possible to develop this analysis in a fairly straightforward manner (Gijzen and Goudriaan, 1989).

Recently three-dimensional models have been used to assess light interception by individual trees. These models have generally been focused on either relatively simple canopy structures or are species-specific, or have considered the crown as a series of layers, or cells with particular foliage characteristics (Myneni and Impens, 1985). Myneni et al. (1990) formulated a three-dimensional leaf canopy model using a modified discrete ordinates method. Myneni (1991) used fractal models of trees to simulate leaf area distributions for modeling the radiative transfer and photosynthesis in a forest canopy. However, most of these studies have simply discussed the adaptive significance of species-specific tree crown architectures as simple allometries between crown dimensions (crown depth, width, or area) and individual sizes (mass, stem diameter at breast height), and have limited the investigations on the effects of individual crown architecture as vertical foliage distributions on the interactions between them (Mohren et al., 1984; Biging and Wensel, 1990; Sinoquet and Bonhomme, 1992).

Typically, crown architecture is described in terms of the amount and spatial distribution of leaf area within the crown and defined as the set of features delineating the shape, size and 
geometry of the tree, and described in terms of the amount and spatial distribution of leaf area within the crown. The crown is assumed to be symmetrical around the tree stem. The radial distribution of leaf area can be approximated by a Gaussian-like pattern (Morales et al., 1996); i.e. the greatest leaf area occurred half the distance between the stem axis and the edge of the crown. However, the direct measurement of leaf area in a three-dimensional canopy is almost impossible (Castro and Fetcher, 1998). Therefore, in order to simplify the modeling task, leaf area in vertically-structured canopy layers can be assumed to be homogeneous, ignoring radial distribution of leaf area around the stem (Kinerson et al., 1974). Furthermore, the vertical distribution of leaf area can be considered to fellow a Weibull statistical pattern (Yong et al., 1993).

Not only are leaves at the top of canopies (or on different sides of isolated trees) normally subject to different energy loads, but the path-lengths along which water must move to different parts of the tree are different (Landsberg, 1986). Procedures to predict the vertical profile of leaf area in the crown were developed (Kinerson and Fritchen, 1971; Schreuder and Swank, 1974; Gray, 1978; Beadle et al., 1982; Massman, 1981; Hagihara and Hozumi, 1986). The beam-path length for each sub-canopy within the canopy can be estimated for varying zenith angles of the sun. A rigorous description of the problem which involves setting up a system of mathematical equations to describe the radiation field at all points in the space within the crown should be considered in the calculation of the radiative transfer process.

It is well established that crown structure has important implications for light interception (Horn, 1971; Givnish, 1984; Kohyama, 1991). Isolated trees, in contrast to those growing in rows, often tend to form in the following shapes - cone, intermediate, cylinder or parabola. These shapes result from the typical growth habits of trees (Sinoquet and Bonhomme, 1992).

The canopy architecture is a complex and dynamic outcome of the evolutionary and ecological interactions and feedbacks between vegetation and environment. As such, canopy structure is a key feature of forest ecosystem processes (Campbell and Norman, 1989; Norman and Campbell, 1989). Thus, understanding and quantifying canopy characteristics is critical in modeling processes in the canopy and in predicting ecosystem responses (Meyers and Paw U, 1987).

\subsection{Solar position and daylength estimates}

Transpiration and water-use models require knowledge of the solar position (defined in terms of zenith and azimuth angles) and day length. The zenith angle of the sun has been shown to influence canopy and soil albedo (Stewart, 1971; Pinker et al., 1980) and absorption (Otterman et al., 1993). The absorption of solar irradiance by trees and soil under trees is significantly larger than the absorption of the bare soil surface, especially at large zenith angles. The absorption of solar irradiance by trees is larger than that by soil under trees at high zenith angles (Otterman et al., 1993) so the efficiency of radiation transfer within canopies increases with increasing zenith angle. Therefore, the zenith angle dependence enters the formulation of radiation transfer to express the partitioning of absorbed solar energy between the tree and the soil components of the surface.

Kock et al. (1990) found that the sun zenith angle has a decisive influence on the spectral reflectance measured above forest trees, even for solar angle variations of less than $10 \%$. Kriebel (1978) has reported the reflectance values at $0.52 \mu \mathrm{m}$ wavelength of four natural 
surfaces; savannah, bog, pasture land and coniferous forest. For all these surfaces, the anisotropy (ratio of the highest to the lowest reflectance value) increases with increasing zenith angle of incidence from about a factor of three to about a factor of ten or more due to the shadowing effects produced by the vertical structure of the canopies (Kriebel, 1978).

In order to estimate the light extinction coefficient, the leaf inclination function and the solar radiation, knowledge of solar position and day length at the time of interest is required. Running and Coughlan (1988) used the latitude of the modeled location and the day of the year as input to the day length calculations of transpiration and energy balance. Nikolov and Zeller (1992) employed the work done by Running and Coughlan (1988) to model solar radiation. Wang and Jarvis (1990) also incorporated the solar position into their radiative transfer model: MAESTRO, using the method developed by Barkstrom (1981). West and Wells (1992) also used the same method (Barkstrom, 1981) to estimate the solar position in a light interception model.

\subsection{Radiative transfer process within the canopy}

Radiation availability is one of the main driving forces behind water uptake by trees. The geometrical architecture of a tree, one of the main factors determining the radiative transfer within the canopy, defines the size, shape and geometry of the tree. The position and the size of trees and their component parts, and the orientation of leaves all play significant roles in the interaction of the tree with the incident radiation. Leaf area and the spatial arrangement of the foliage, branches, and stems determine the transmission of radiation through a forest canopy.

Radiative transfer in vegetation canopies has been studied for decades ( Ross, 1981; Myneni and Ross, 1990; Law et al., 2000). A variety of models have been developed, ranging from models using the simple Beer's law to complex computer simulation models (Wang and Baldocchi, 1989; Myneni et al., 1990; Andrieu et al., 1995). Theoretical basics and reviews of different models can be found in Ross (1981), Goel (1988) and Myneni and Ross (1990).

The leaf-angle distribution which is a fundamental property of plant canopy structure is needed for computing distributions of leaf irradiance (Campbell, 1990) along with radiation transfer through canopies and extinction coefficients. The leaf inclination angle $\left(\theta_{\mathrm{L}}\right)$ is defined as the angle between the vertical and a normal to the leaf surface, and the leaf azimuthal angle $\left(\theta_{\mathrm{K}}\right)$ is the angle about the points of the compass between a normal to the leaf surface and the solar beam. Idealized leaf inclination density functions have been widely used to approximate actual leaf angle distributions (Ross, 1981). Several formulae have been given for uniform leaf inclination angles, but randomly distributed azimuthal angles (Lang, 1986; Goudriaan, 1988; Campbell, 1990). The leaf inclination described by one mean leaf angle over-evaluates the effect of the leaf orientation on radiative exchanges (Lemeur, 1973). A two-dimensional probability function $g\left(\theta_{\mathrm{L}} \theta_{\mathrm{K}}\right) d \theta_{\mathrm{L}}, d \theta_{\mathrm{K}}$ can be used to describe the fraction of the leaf area oriented with the inclination, $\theta_{\mathrm{L}}$ and the azimuth $\theta_{\mathrm{K}}$ (Lemeur, 1973).

The mathematical description of the leaf orientation distribution is a troublesome part in modeling radiative transfer through a vegetation canopy. Yet it is important because it is the only representation of the canopy geometrical structure, and directly related to the Gfunction (Ross, 1981) and the canopy scattering phase function - the two most important functions in the radiative transfer theory. Early practices were either to classify the leaf 
orientation distributions as erectophile, planophile, spherical, extremophile, or plagiophile, and give a mathematical description for each of these leaf orientation distributions (De Wit, 1965), or to represent a leaf orientation distribution by frequencies in three or nine leaf angle classes (Goudriaan, 1977, 1988).

\subsubsection{Radiation transfer through the canopy}

Several studies have been done to examine the influence of canopy architecture on penetration of radiation in theoretical models (Kira et al., 1969; Oker-Blom and Kellomaki, 1983; Campbell and Norman, 1989). Many of these studies used the Beer-Lambert model, which defines canopy light penetration as proportional to the cumulative leaf area index (e.g. Monsi and Saeki, 1953). Small within-species variations in light extinction have often been attributed to changes in solar altitude during sampling of under-canopy light flux density (Campbell and Norman, 1989) rather than to intra-specific variability. Recent results, however, suggested substantial variation in light extinction for several tree species (Gholz et al., 1991). Models have often been used to estimate light penetration in forest stands of different LAI (Dalla-Tea and Jokela, 1991; Gholz et al., 1991).

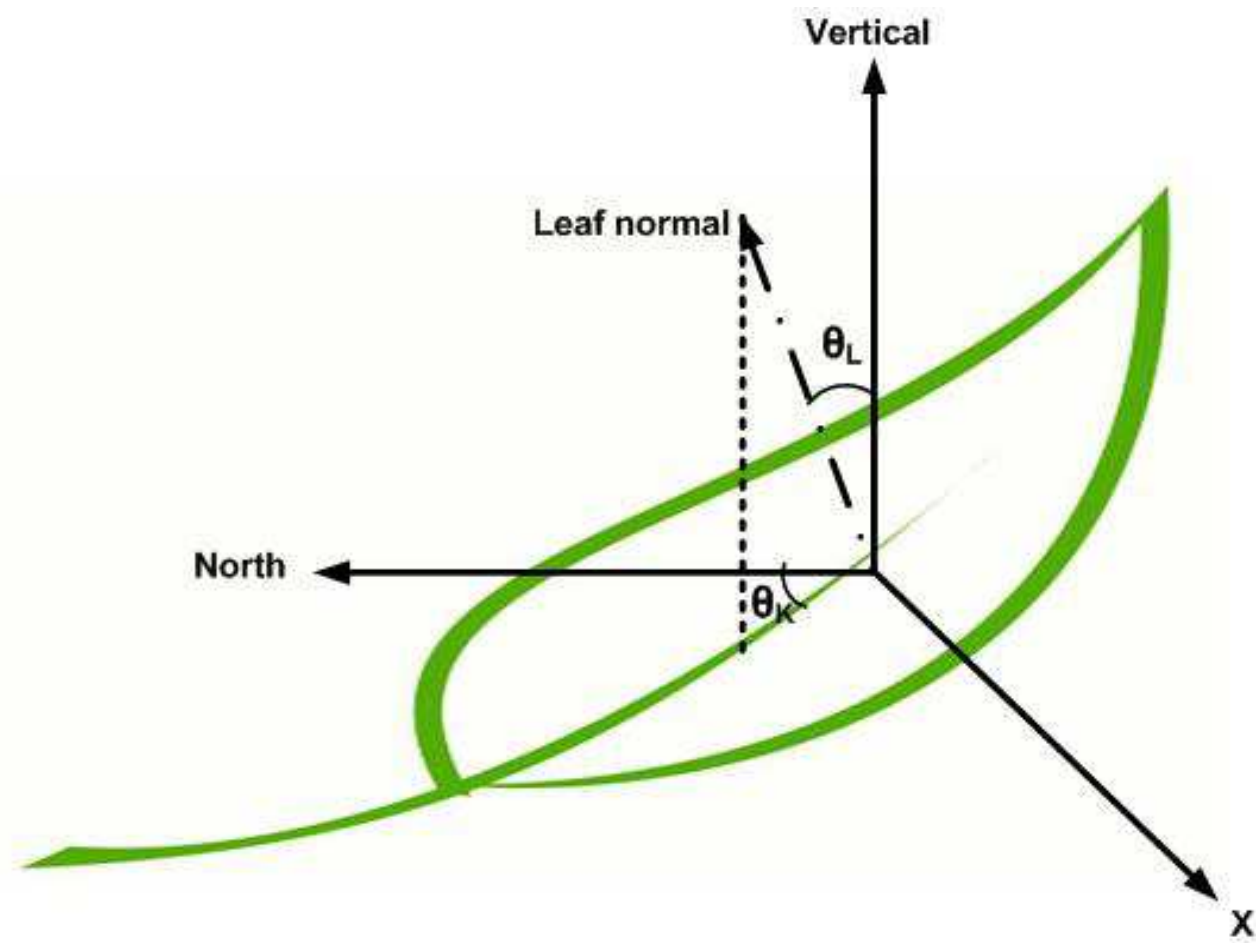

Fig. 3. Diagrammatic representation of the orientation of the normal to a leaf surface

The leaf angle distribution, which is a mathematical description of the angular orientation of the leaves in the canopy, is needed for computing distributions of leaf irradiance along with radiation transfer through canopies and extinction coefficients (Campbell, 1990). The leaf 
angle distribution consists of two angles i.e., the leaf inclination angle $\left(\theta_{\mathrm{L}}\right)$ and the leaf azimuthal angle $\left(\theta_{\mathrm{K}}\right)$. The $\theta_{\mathrm{L}}$ is defined as the angle between the vertical and a normal to the leaf surface, and the $\theta_{\mathrm{K}}$ is the angle about the points of the compass between a normal to the leaf surface and the solar beam (Campbell, 1990) (Fig. 3). Idealized leaf inclination density functions have been widely used to approximate actual leaf angle distributions. If all leaves are inclined at a constant angle (mean leaf angle), $\theta_{0}$, then, the inclination angle distribution, $g\left(\theta_{\mathrm{L}}\right)$ is given by (Ross, 1981):

$$
g\left(\theta_{L}\right)=\delta\left(\theta_{L}-\theta_{0}\right) \sin \theta_{L}
$$

where $\delta\left(\theta_{\mathrm{L}}-\theta_{0}\right)$ is the Dirac delta function. A horizontal distribution results when $\theta_{0}=0$, a vertical or cylindrical distribution when $\theta_{0}=\Pi / 2$, and a conical distribution when $\theta_{0}$ is between these values. In most plants the upper (adaxial) surfaces of the leaves face the upper hemisphere so that $\theta_{\mathrm{L}}$ varies between $0^{\circ}$ and $90^{\circ}$ whereas $\theta_{\mathrm{K}}$ varies between $0^{\circ}$ and $360^{\circ}$. The leaf inclination described by one mean leaf angle over-evaluates the effect of the leaf orientation on radiative exchanges (Lemeur, 1973). A two-dimensional probability function $g\left(\theta_{\mathrm{L}} \theta_{\mathrm{K}}\right) d \theta_{\mathrm{L}}, d \theta_{\mathrm{K}}$ can be used to describe the fraction of the leaf area oriented with the inclination, $\theta_{\mathrm{L}}$ and the azimuth $\theta_{\mathrm{K}}$ (Lemeur, 1973). This function expresses the probability that a leaf has an inclination within $\theta_{\mathrm{L}}$ and $\theta_{\mathrm{L}}+d \theta_{\mathrm{L}}$ and an azimuth within $\theta_{\mathrm{K}}$ and $\theta_{\mathrm{K}}+d \theta_{\mathrm{K}}$. Therefore, integration over $\theta_{\mathrm{L}}$ and $\theta_{\mathrm{K}}$ leads to (Ross, 1975):

$$
\int_{\theta_{K}=0}^{\theta_{K}=2 \pi} \int_{\theta_{L}=0}^{\theta_{L}=\pi / 2} g\left(\theta_{K}, \theta_{L}\right) d \theta_{K} d \theta_{L}=1
$$

It is possible to estimate the value of light extinction coefficient for different sets of orientation of the leaves and the direction of incoming radiation by considering the projected area of solids having the angle distributions for the given distribution function (Monteith, 1975). The value of the light extinction coefficient for direct beam radiation is related to its mean cosine of incidence on the leaf surfaces. For a single flat leaf, the cosine of the angle of irradiance is described by $\theta_{\mathrm{L}}, \theta_{\mathrm{K}}$, and $\varphi_{\mathrm{L}}$, and the $\operatorname{cosine} t\left(\varphi_{\mathrm{L}}, \theta_{\mathrm{L}}, \theta_{\mathrm{K}}\right)$ is determined as (Ross, 1975):

$$
t\left(\varphi_{L^{\prime}} \theta_{L^{\prime}} \theta_{K}\right)=\cos \varphi_{L} \cos \theta_{L}+\sin \varphi_{L} \sin \theta_{L} \cos \theta_{K}
$$

The distribution of $t$ is uniform with $\theta_{\mathrm{K}}$ if no preferred azimuthal angle is assumed. The cumulative distribution function of $t$ can be found by increasing $\theta_{\mathrm{K}}$ from $-\Pi$ to 0 . With symmetrical geometry, the other half of the azimuthal circle (from 0 to $\Pi$ ) can be omitted. $\theta_{K}$, at the range from $-\Pi$ to 0 , is equivalent to the range of $0-1$ for the cumulative distribution probability $S$. The average value of $t$ can be found as the integral of $t$ with respect to $S$. This is the same quantity as the average projection of the leaves into the direction of the solar beam called the $O$ function by De Wit (1965) and the G function by Ross (1975) and Goudriaan (1989).

\subsubsection{Radiation scattering}

As pointed out by Myneni et al. (1988), the canopy scattering phase function determines how realistically the physics of the radiation transport process in vegetation is represented (Ross, 
1981). Therefore, the scattering phase function should be one of the most important factors determining the level of accuracy of the radiative transfer process.

With the assumption of isotropic scattering for leaf elements, Sellers (1985) found a simple expression for the scattering phase function, and solved the equations analytically. However, the isotropic scattering assumption is a rather crude approximation for real leaf elements. As a consequence of this assumption, scattering does not change with the relative magnitudes of the reflection and transmission coefficients for a given leaf scattering coefficient. The unrealistic implications of this shortcoming can be seen easily in the expression for the single scattering albedo for a semi-infinite horizontal leaf canopy. It is a quarter of the leaf scattering coefficient (the leaf scattering coefficient equals the sum of the leaf reflection and transmission coefficients). Since only single scattering is considered, radiation which is transmitted through a leaf is never able to escape from the canopy and cannot contribute to the canopy reflection. Thus, the transmission coefficient is unrelated to the canopy single scattering albedo, and the only relevant leaf optical parameter is the leaf reflection coefficient. For most situations, canopy hemispheric reflectance as given by the isotropic two-stream model, proposed by Dickinson (1983) and further developed by Sellers (1985), hardly changes with the relative magnitudes of the reflection and transmission coefficients. Although the isotropic two-stream approximation model has widely been applied (Sellers, 1985), comprehensive testing of the model has been limited.

Although Hassika et al. (1997) stated that the radiation rescattered by the crowns can be neglected, estimates using the Kubelka-Munk equations that indicate this term is small, up to secondary scattering may be good enough for the canopy radiative process.

\subsubsection{Radiative transfer process with the canopy}

Radiative transfer models are based on more or less abstract representations of reality, usually in relation to the aim and scale of the simulation; models based on a uniform-canopy hypothesis and on the architectural description of tree crowns represent the opposite extremes of this range. Radiative models of the first type can be used to simulate light interception by agricultural crops and uniform forests (Wang and Baldocchi, 1989) and to provide insight into the role of specific characteristics such as leaf angle and leaf area index or vertical distribution of leaf characteristics such as leaf mass per unit area or volume (Gutschick and Weigel, 1988). Models in the second group work at the same scale as leaves or leaf groups and are used to investigate the relationship between canopy architecture and radiative regime in complex heterogenous canopies (Myneni et al., 1990). For individual trees, qualitative models of branching have been used to describe the development of form (Halle et al., 1978), but these model applications have had limited ecological applicability in understanding how specific architectures influence light capture. Two dimensional models have been used to explore how branch angle and length influence leaf-overlap and, hence, the efficiency of light capture (Fisher et al., 1981). These approaches were limited in that they considered the interception of light from only a single direction, whereas, in reality, diffuse radiation comes from many directions and the direction of the solar beam changes during the day. Neither of these model types can address some of the research tasks typical for forest ecology (Pukkala et al., 1993).

Myneni et al. (1990) formulated a modified discrete ordinates method for a threedimensional leaf canopy. Myneni (1991) used fractal models of trees to simulate the 
radiative transfer and photosynthesis in a forest canopy. Recently, three-dimensional models such as Myneni et al.'s (1990) have been used to assess light interception by individual trees. These models have generally focused on either relatively simple canopy structures or are species-specific, or have considered the crown as a series of layers, or cells with particular foliage characteristics (Myneni and Impens, 1985; Ryel et al., 1993). The foliage intercepts most of the radiation captured by the canopy, and an increased foliage area decreases the penetration of radiation. It is normally assumed that only the crown intercepts radiation; stems, branches and fruits are 'invisible' for the light beams (Jarvis and Leverenz, 1983; Cannel et al., 1987).

Short-wave direct radiation $(R b s)$ and diffuse radiation $(R d s)$ are the main spectral characteristic for many radiative transfer models Myneni (1991). However, Kjelgren and Montague (1998) stated that trees over asphalt had consistently higher leaf temperatures than those over turf due to the interception of the greater upwards long-wave radiation fluxes due to the higher surface temperatures of the asphalt over turf. When bare soil between trees exits, upwards long-wave radiation may contribute substantially to the energy balance in the canopy. Therefore, the radiation above, within and below the canopy can be separated in terms of short-wave radiation $(R b)$ and long-wave radiation $(R l w)$, and $R b$ is separated into $R b s$ and $R d s$ radiation.

The characterization of the magnitude and direction of the diffuse and direct components of incident radiation is required as the light distribution within the canopy depends on the spectral optical properties of the leaves and the soil. Therefore, the optical properties of the vegetation elements and the soil are important factors to determine radiative transfer within the canopy.

\subsection{Canopy-energy balance}

Radiant energy received from the sun and the atmosphere is exchanged for latent and sensible heat by plants and the soil surface. Sensible heat is transferred because of the temperature difference between trees and surrounding air, and it moves by convection, advection and diffusion. The relative amounts of latent and sensible heat exchanged by plants and soil surfaces are understood to be mediated by resistance to water movement in aqueous and vapour phases between the plant or the soil and the atmosphere.

Gates (1962) pioneered leaf energy budget investigations in plant ecology. Although the interaction between a canopy and its radiant energy environment can be extremely complex, a simplified approach that serves to introduce basic concepts is now well-established. According to energy conservation, the heat gain by radiation should be equal to the heat losses in the canopy when leaf temperature is constant.

The leaf temperature of trees is higher at the upper part than at the lower in daytime (He et al., 1996; Zermeno and Hipps, 1997) and the difference between leaf temperatures at a depth of $20 \mathrm{~m}$ and $11 \mathrm{~m}$ is about $12{ }^{\circ} \mathrm{C}$ around noon (Miyashita and Maitani, 1998). Therefore, it is clear that energy balance cannot be applied uniformly throughout the canopy. Describing the long-wave radiative transfer is further complicated in plant canopies because leaf elements are also long-wave radiation sources (Rotenberg et al., 1999). This fact complicates the description of long-wave radiative transfer in plant canopies. To make the situation even worse, in order to solve the leaf temperature from 
the energy balance equation, the absorbed long-wave radiation, which in turn depends on the temperature of the leaf, must be known in advance. Solving the long-wave radiative transfer problem relies on iterative search methods which can be computationally intensive for a canopy process model. Complicating this, the energy balance equation has (potentially up to) four roots because long wave radiation is proportional to the fourth power of temperature. At least one of the roots should be bio-physically sensible. Unfortunately there is no guarantee that iterative search methods will converge on the correct root and sometimes yield bifuricated or chaotic solutions (Baldocchi, 1994). To overcome this difficulty, a polynomial expression can be introduced in order to solve the energy balance equation analytically for leaf temperature. Doing so avoids the involvement of a complex algorithm with numerous partial derivatives and iterations in energy balance calculations such as that used by Cienciala et al. (1994). Applying the energy balance calculation in a horizontally- or/and vertically-structured canopy allows us to investigate spatial variations of leaf temperature.

The sensible heat flux can be considered to be proportional to the difference between the radiometric temperature which is identical to canopy surface temperature and the air temperature at a reference height, and inversely proportional to aerodynamic resistance.

The large amount of standing biomass in a forest causes a substantial amount of net radiation to be transformed into canopy heat storage, further affecting evapotranspiration (Jarvis, 1976). The heat storage, which is mostly in biochemical reactions represents a fraction of radiation over a very short period (Montheith, 1975) is about $8 \%$ of the Rnet (Jones, 1992).

\subsection{Scalar variations within the canopy}

Many canopy models have been developed to describe the exchange of sensible and latent heat between plant canopies and the atmosphere (Baldocchi, 1993). An important function of these models is to predict the mean profile of humidity and temperature of the air in the canopy, because transpiration at each canopy level depends on the air temperature and humidity at that level.

To calculate these profiles, some assumptions are made about the turbulent transport processes within the canopy. The most common assumption has been that turbulent convection conveys scalars (heat and vapour pressure), down local concentration gradients by a turbulent diffusion process. As such, these models have been based on K-theory (Waggoner and Reifsnyder, 1968). The K-theory has been challenged by observations of fluxes of scalars moving in directions opposed to their local concentration gradients within plant canopies (Denmead and Bradley, 1985). New theories have been developed to explain counter-gradient transport, but are yet to produce an accurate method to demonstrate scalar transport processes within the canopy. Raupach (1989), for instance, stated that because of the strong influence of source distribution and the relatively weaker influence of the fine details of the inhomogeneous wind field, a rather simple model for the wind field in the canopy is probably all that is necessary to calculate scalar concentrations in the vertical dimension quite accurately. Simple, half-order closure modelling which assumes a uniform scalar profile does not yield large errors in the computation of flux densities because the source-sink formulation of fluxes is relatively insensitive to changes in scalar concentrations in the profile and the scalar gradients are small (Baldocchi, 1992). 
Sensible and latent heat transfer processes consider the environmental gradients that occur between some reference level outside the canopy and sub-canopies inside the canopy in a three-dimensional modeling framework. Gradients of these quantities exist between the bulk air and sub-canopies within the canopy and drive the fluxes from (or to) the canopy. To evaluate these gradients, for example in a tree canopy, linkages between the strengths of the respective sources and sinks and scalar concentration in the sub-canopy must be considered. These linkages arise because the rate at which material is released (or taken up) affects the local scalar concentration in sub-canopies within the canopy, and the rate of leaf emission, (or uptake), depends on the local scalar concentration. Implicitly, it can be assumed that the atmosphere within the sub-canopy is well mixed and no inter- or intra-layer mixing within the canopy. It can be assumed further that water vapor outside any sub-canopy (but inside the canopy) is removed without affecting the micro-environment along its pathway to the bulk air outside the canopy. However, it is recognized that these assumptions are not accurate, but a reasonable answer to a difficult, if not unquantifiable, situation. Despite these assumptions, the humidity deficit between the various sub-canopies and the bulk air is not equal as long as the modelling process simulates;

1. surface temperature with respect to the sub-canopy location within the canopy, and

2. vertical profiles of air temperature and wind speed outside the canopy.

The diurnal variations of wind speed and air temperature and humidity of air can be calculated using empirical equations given in the literature (Landsberg and James, 1971; Dogniaux 1977; Wu, 1990; Eckersten, 1991; Paw U et al., 1995). The shape of the diurnal scalar curves is modeled with a variety of methods with varying degrees of complexity. These methods include linear models and curve-fitting models based typically on sine or Fourier analysis (De Wit et al., 1978; Worner, 1988; Fernandez, 1992).

The vertical wind profile affects the boundary layer resistance for heat and water vapor transfer (Landsberg, 1986). Although tree edges can modify the wind speed, and wind direction both inside and outside of the canopy, it is normally assumed that wind speed does not change while passing through the canopy.

Air temperature affects latent and sensible heat flux. A simple method is applied to determine the air temperature inside the canopy from the air temperature outside the canopy and sensible heat flux. Diurnal variation of air temperature can also be estimated using a sinusoidal progression. There are several studies that have been carried out to determine the vertical profile of the air temperature $(\mathrm{Ta})$ above the canopy $(\mathrm{Wu}, 1990)$, but such knowledge does not exist in the same simple manner for profiles within the canopy. Paw U et al. (1995) used a form of surface renewal analysis by assuming that under unstable conditions (canopy warmer than the air), any rise in the temperature profile represents air being heated by the canopy, and under stable conditions (canopy cooler than air) any temperature drop represents air being cooled by the canopy. The air temperature normally changes in a sinusoidal progression during the day and a decreasing exponential curve at night (van Engelen and Guerts, 1983).

To estimate relative humidity $(R h)$ rather than interpolating it over time using synoptic values, it is more appropriate to use linear interpolation of the absolute air humidity $(\mathrm{Ha})$ (Eckersten, 1991). 
A knowledge of solar radiation is of interest in studies relating to crop evapotranspiration, forest transpiration and for solar energy applications. The incident global radiation (350$3000 \mathrm{~nm}$ ) on the earth's surface (Rnet) is a product of incident radiation outside the atmosphere $(R o)$ and the atmospheric transmissivity, which is dependent upon the degree of cloudiness.

If uniform cloudiness is assumed over the day, the mean irradiance $(R n \mathrm{M})$ is computed from the ratio of the daily sum of actual global radiation to the daily sum of global radiation from a clear sky. The effects of cloudiness on radiation within the day can be approximated by introducing a factor that varies according to cloudiness.

\subsubsection{Separation of solar radiation into direct and diffuse components}

For the radiation-mediated processes of a canopy energy study, it is not sufficient to know the total incoming radiation, but estimates of the direct short wave, diffuse short wave and long wave components are required. Bristow et al. (1985) established a relationship to estimate hourly diffuse transmittance (Tdd) from hourly total transmittance $(T t d)$. Diffuse radiation can then be obtained by multiplying $T d d$ by potential solar radiation. The difference between total incident radiation and diffuse radiation is the direct beam radiation.

Apart from Bristow et al. (1986), there are several references for the partition of global radiation available (Weiss and Norman, 1985), but no general agreement on the method to be used to estimate the proportions. There are several methods to calculate the proportions of $R b$ and $R d s$ in global radiation, both empirical and theoretical (Liu and Jordan, 1960; Weiss and Norman, 1985; Bristow et al., 1986). Although empirical methods give better results, their validity is limited to a particular place and time. Theoretical methods are preferable because they are more general, but no method is completely satisfactory for all latitudes and seasons (Castro and Fetcher, 1998). Many factors including clouds, aerosols, etc., affect the scattering of radiation in the atmosphere and therefore the proportion of $R d s$. Consequently, a theoretical method such as that described in this section for the partition of $R b$ and $R d s$ in global radiation can be used.

\subsubsection{Long-wave radiation}

Long-wave radiation comes from objects with extended radiating surfaces such as clouds, sky, rocks, soil, water, and vegetation or animals. Arbitrary limits of 3 and $100 \mu \mathrm{m}$ are usually taken to define the long-wave spectrum (Monteith and Unsworth, 1990). Downward long-wave radiation (Rlw $\downarrow$ ) can be given as a function of air temperature ( $\mathrm{Ta}$ in ${ }^{0} \mathrm{C}$ ) and the vapour pressure $\left(e_{a}(\mathrm{Ta})\right.$ in $\left.\mathrm{hPa}\right)$ (Brutsaert, 1982).

\subsubsection{Photosynthetically active radiation}

In micrometeorology, special attention is paid to photosynthetically active radiation $\left(R_{P A R}\right)$, which is defined as radiation in the spectral region between 400 and $700 \mathrm{~nm}$ (Monteith, 1975). $R_{P A R}$ is needed when stomatal resistance is calculated. The calculation of $R_{P A R}$ is performed by means of a conversion factor $C_{P A R}$ as a function of solar zenith angle $\left(\varphi_{\mathrm{L}}\right)$ is given by Perelyot (1970). 


\subsection{Water flow resistance process in the canopy-atmosphere process}

The turbulent transport between canopies and the bulk of the atmosphere depends on the turbulent nature of the planetary boundary layer (Meyers and Paw U, 1986 and 1987). In the transfer of water vapor to and from trees, some exchanges occur by molecular diffusion such as the passage of water through stomata. The flux of diffusing gas $\left(\mathrm{kg} \mathrm{m}^{-2} \mathrm{~s}^{-1}\right)$ can then be equated to the concentration difference $\left(\mathrm{kg} \mathrm{m}^{-3}\right)$ over a diffusion resistance $\left(\mathrm{s} \mathrm{m}^{-1}\right)$ as given by Fick's law. In the process of the diffusion of water vapor away from the leaves, the stomatal resistance $\left(R_{\mathrm{t}}\right)$ accounts for diffusion from the evaporation sites within the leaf to the leaf surface, while the leaf boundary layer resistance $\left(R_{\mathrm{a}}\right)$ accounts for diffusion from the surface to the well-mixed surrounding air. Both the stomatal resistance and the leaf boundary layer resistance are highly dependent on the size, shape and surface properties of the leaves, and wind velocity.

\subsubsection{Stomatal resistance}

Empirically established stomatal resistance, which is the most important factor determining transpiration from high vegetation especially forests, has marked variation within the canopy as well as over the day and the season. Stomatal resistance $\left(R_{\mathrm{t}}\right)$ depends both on soil and atmospheric factors. These factors are short-term changes in leaf water potential, vapour pressure deficit, solar flux, leaf temperature, ambient carbon dioxide concentration and significant drying of the soil (very negative soil water potential). Therefore, there is clearly a need to describe the response of $R_{\mathrm{t}}$ to atmospheric factors as well as soil water status. Estimation of stomatal resistance has generally involved two approaches;

a. serially integrating the stomatal resistance of individual layers, weighted by leaf area, or

b. using measured values of latent heat flux and other relevant variables in a stand-level equation.

Baldocchi et al. (1991) presented an excellent overview of the strengths and weaknesses of different approaches for estimating canopy stomatal resistance. As discussed in their paper, the above mentioned approaches may not yield the same results. The former is primarily a physiological parameter whereas the latter involves additional eco-physiological factors within the canopy. The latter also includes the contribution of soil evaporation. Baldocchi $e t$ al. (1991) developed a multi-layer canopy stomatal conductance model in which the spatial variation of canopy structure and the radiative transfer within the canopy were taken into account.

Jarvis (1976) has modelled the stomatal resistance as a function of solar radiation, temperature, specific humidity deficit, leaf water potential, and ambient $\mathrm{CO}_{2}$, using a nonlinear least squares technique. Based on the Jarvis work, Stewart (1988) developed a model in which the stomatal resistance was related to solar radiation, temperature, specific humidity deficit, soil moisture deficit and leaf area index. A semi-empirical stomatal resistance model was proposed by Ball et al. (1987). After analyzing Ball's model, Aphalo and Jarvis (1993) have proposed a new model, which views the model as a description of the relationship between $\mathrm{CO}_{2}$ flux rate and stomatal conductance, rather than as a model of stomatal conductance alone. Ball's empirical model was later modified by Leuning (1995). 
Lacking independent estimates of canopy surface resistance for independent assessments of the Penman-Monteith equation, many researchers assumed that canopy surface resistance is equivalent to the integrated stomatal resistance. The adaptation of this assumption has received theoretical (Finnigan and Raupach, 1987; Kelliher et al., 1994; Raupach, 1995) and experimental (Baldocchi et al., 1987) criticism over the years. Under the optimal environmental conditions required to achieve 'minimum' resistance (ample water supply, non-extreme temperature, and fully developed non-senescent leaves), stomatal resistance $\left(R_{\mathrm{t}}\right)$ varies through the canopy only in response to variation in photosynthetically active radiation (Kelliher et al., 1994). However, $R_{\mathrm{t}}$ decreases with radiation and increases with the vapor pressure deficit of the atmosphere (Lohammar et al., 1980). Soil water content varies with uptake by roots as well as with rainfall and irrigation, and soil water potential directly affects $R_{\mathrm{t}}$ (Jones, 1982). Air temperature changes in a sinusoidal fashion during the day (Goudriaan and van Laar, 1994) and affects $R_{\mathrm{t}}$ (Aphalo and Jarvis, 1991). White et al. (1999) modified $R_{\mathrm{t}}$ by describing the response of light, air temperature and vapor pressure deficit, but soil water potential directly affects $R_{\mathrm{t}}$ in some circumstances (Jones, 1992), but in many cases, soil water potential is considered to affect leaf water potential, which in turn controls $R_{\mathrm{t}}$ (Lynn and Carlson, 1990). Therefore, $R_{\mathrm{t}}$ as a function of leaf water potential may be more accurate.

A procedure to describe the behavior of $R_{\mathrm{t}}$ can be given as a function of photosynthetically active radiation, vapor pressure difference, air temperature and soil moisture deficit. Although $R_{\mathrm{t}}$ is considered to be influenced by changes of $\mathrm{CO}_{2}$ concentration (Hall, 1982), it is typically not included, because in most cases it was found to be almost constant (about 4 ppm variation) (Yang et al., 1998). Baker (1996) also supported the case for insignificant variation of the $\mathrm{CO}_{2}$ profile in forests.

As the radiation interception and scalar profiles are formulated for each sub-canopy within the crown, it is possible to estimate $R_{\mathrm{t}}$ individually for each sub-canopy, and thus avoid the integration of $R_{\mathrm{t}}$ for the whole canopy. Similarly, $R_{\mathrm{a}}$ calculated for each sub-canopy in the canopy is not required to be integrated over the total leaf area of the canopy. One can observe that stem resistance also contributes to the overall resistance of the canopyatmosphere system. However, in resistance studies by Melchior and Steudle (1993), it was found that resistance to water flow was usually negligible where the xylem had already matured.

\subsubsection{Leaf boundary layer resistance}

The average thickness of the boundary layer is related to the leaf size. Thus small leaves have thin boundary layers which give small boundary layer resistances whereas large leaves have thick boundary layers with large boundary layer resistances and temperatures which may differ substantially from that of the surrounding air (Grace, 1983). At high wind speeds, the boundary layer is thinner than at low speeds and the resistance correspondingly smaller. The canopy slows down the air flow and creates a turbulent boundary layer. Transport of heat or water vapor through this layer occurs by turbulent diffusion, at a rate determined by the turbulent structure of the air which, in turn, is determined by the wind speed and the aerodynamic roughness of the canopy. The main determinants of boundary layer resistance are therefore leaf size and wind speed, with leaf form exerting a secondary effect through its effect on turbulence (Nikolov et al. 1995). 
Values of boundary layer resistance $\left(R_{a}\right)$ for individual leaf components can be estimated using engineering equations or empirical relationships. A comprehensive analysis of how to quantify the leaf boundary layer can be found in work done by Campbell (1977), Grace et al. (1987), Gates (1980), Monteith and Unsworth (1990) and Nikolov et al. (1995).

\section{Combining below- and above-ground processes}

A tree is an organism with leaves and has a capacity to store water in its boles. The transport of water through the water storage in the tree causes hysteresis between rates of soil water uptake and transpiration (Jones, 1982). Landsberg (1986) pointed out that it becomes necessary to include the fluxes in and out of storage in models that predicts the time course of leaf and other tissue water potentials. Trees use stored water to keep stomata open and maintain transpiration in the face of limiting soil moisture or excessive atmospheric demand. Therefore, water movement can be modelled in terms of water potentials and resistances via exchangeable water storages.

Having identified the major soil and environmental variables affecting the movement of water from soil to the atmosphere through trees and the subsequent changes in flow associated with resistances in the previous sections, it is possible to combine all this understanding of below- and above-tree water movement into a predictive model. Soil and root resistances, and soil water potential come from the below-ground models whereas the above-ground models contribute stomatal $\left(R_{t p}\right)$ and boundary layer $\left(R_{a} W_{p}\right)$ resistances, vapor densities at the surface and the air temperature. Initial rates of water uptake $\left(F_{U p}\right)$ and transpiration $\left(F_{\mathrm{TP}}\right)$ are used to estimate the exchangeable water storage $\left(V_{p}\right)$ and leaf water potential $\left(\psi_{\mathrm{Lp}}\right)$. Since $\psi_{\mathrm{Lp}}$ is a function of $R_{t p}$, an iterative procedure is required to estimate the final value of $F_{\mathrm{TP}}$.

It is possible to eliminate the intermediate water potentials mathematically by neglecting any storage of water at the surface or in the tree (Thornley and Johnson, 1990). Campbell (1991) has employed a multi-layered root zone to include variable rooting density conditions into the water uptake estimations.

Monteith (1980) stated that latent energy for evaporation must be supplied from an external source (according to the law of conservation of energy), and the saturated water vapor in contact with the wet surface must be swept away and replaced by dry air which becomes saturated in turn. To sustain vaporization, however; there must not only be a continual supply of energy, but also an inward flow of liquid water from the soil or the plant (McIlroy, 1984). Accepting this, it is reasonable to assume that there is exchangeable water stored in the plant (Weatherley, 1970 and Jarvis, 1975). Until recently, tree water storage has been largely ignored in soil-tree-atmosphere models. The exchangeable water in the plant allows transpiration to exceed, equal or be less than water uptake by the roots at any given time. This concept of exchangeable water in the plant was used by Kowalik and Ekersten (1984) to formulate a continuous simulation model for transpiration and was solved numerically.

\subsection{Modelling water uptake and transpiration}

The flow of water through the soil-tree-atmospheric continuum can be divided into three components: (a) water uptake by roots; (b) exchangeable water in storages; and (c) water 
loss by leaves. All necessary components related to (a) are given in Section 2 whereas for (c), they are given in Section 3.

The essential concept is that the water storage in the canopy for a given period is governed by water lost by transpiration and water supplied by roots. The volumetric change of the water storage in the sub-canopy $P$ during one time step is the difference between water uptake and transpiration:

$$
\delta V_{p}=\int_{t-\delta t}^{t}\left(F_{U_{P}}-F_{T_{P}}\right) d t
$$

where $F_{\mathrm{Up}}$ is root water uptake to computational sub-canopy $P\left(\mathrm{~kg} \mathrm{~h}^{-1}\right), \delta V_{P}$ is change of the amount of exchangeable water stored for a given time $(\mathrm{kg})$ and $F_{\mathrm{TP}}$ is transpiration from the sub-canopy $P\left(\mathrm{~kg} \mathrm{~h}^{-1}\right)$. The purpose of introducing the exchangeable water stored in the tree is to show the effects of stored water in a coupled soil-tree-atmospheric model on the transpiration flux and leaf water potential. $V_{P}$ is the state variable. The water uptake by trees, $F_{\mathrm{U}}$, and transpiration from the leaves, $F_{\mathrm{T}}$, are the main driving variables.

It is possible to eliminate intermediate water potentials mathematically by neglecting any storage of water at the surface or in the tree. Thus, the water flow from the soil to the plant (Thornley and Johnson, 1990) was written as:

$$
F=\frac{\psi_{s}-\psi_{L}}{R_{s}+R_{r}}
$$

where $R_{s}$ is flow resistance from bulk soil to root surface $\left(\mathrm{kg}^{-1} \mathrm{~m}^{4} \mathrm{~s}^{-1}\right), R_{r}$ is flow resistance from root surface to xylem $\left(\mathrm{kg}^{-1} \mathrm{~m}^{4} \mathrm{~s}^{-1}\right), \psi_{\mathrm{s}}$ is soil water potential $\left(\mathrm{J} \mathrm{kg}^{-1}\right)$ and $\psi_{\mathrm{L}}$ is leaf water potential $\left(\mathrm{J} \mathrm{kg}^{-1}\right)$.

Equation 14 is not particularly useful because it assumes a constant rooting density with respect to depth in the soil. To extend the equation to include variable rooting density conditions, (the root volume is assumed to be made up of zones with constant root densities), Campbell (1991) has employed a multi-layered root zone as follows:

$$
F_{U}=\int_{i=1}^{n}\left(\frac{\psi_{s_{i}}-\psi_{L}}{R_{s_{i}}-R_{r_{i}}}\right)
$$

The amount of water uptake by roots for the sub-canopy $\mathrm{P}\left(\mathrm{kg} \mathrm{h}^{-1}\right)$ can be computed by expanding equation 8 as follows (after Thornley and Johnson, 1990; Campbell, 1991; Eckersten, 1991):

$$
F_{U_{P}}=\int_{i=1}^{l}\left(\frac{\psi_{s_{i}}-\psi_{L_{P}}-Z_{P}}{R_{s_{i}}+R_{r_{i}}+R_{l_{i}}+R_{s t}}\right) L A_{P} 3600
$$

where $\psi_{\mathrm{si}}$ is soil water potential in the soil layer $i\left(\mathrm{~J} \mathrm{~kg}^{-1}\right), \psi_{\mathrm{Lp}}$ is leaf water potential in the sub-canopy $P\left(\mathrm{~J} \mathrm{~kg}^{-1}\right), l$ is number of soil layers, $R_{s i}$ is soil resistance for the water flow from soil to the root surface in the soil layer $i\left(\mathrm{~kg}^{-1} \mathrm{~m}^{4} \mathrm{~s}^{-1}\right), R_{r i}$ is root radial resistance for the water 
flow in roots in the soil layer $i\left(\mathrm{~kg}^{-1} \mathrm{~m}^{4} \mathrm{~s}^{-1}\right), R_{l i}$ is axial resistance for the water flow in roots in the soil layer $i\left(\mathrm{~kg}^{-1} \mathrm{~m}^{4} \mathrm{~s}^{-1}\right), R_{s t}$ is stem resistance (assumed negligible), $z_{\mathrm{p}}$ is gravitational potential $\left(\mathrm{J} \mathrm{kg}^{-1}\right)$ and $L A_{P}$ is leaf area of the sub-canopy $P\left(\mathrm{~m}^{2}\right)$.

The transpiration rate is driven by the difference in vapour pressure between that inside the stomatal cavities and that of the air outside. When the air in stomatal cavities is assumed to be saturated, the transpiration rate in sub-canopy $P\left(\mathrm{~kg} \mathrm{~h}^{-1}\right)$ can therefore be calculated as (Eckersten, 1991):

$$
F_{T_{P}}=\frac{\rho c_{P}\left(e_{S}(T s)_{P}\right)-e_{a}(T a)_{P}}{\lambda \gamma\left(R t_{P}+R a_{P}^{W}\right)} 3600
$$

where $\rho$ is the specific density of moist air $\left(\mathrm{kg} \mathrm{m}^{-3}\right), \gamma$ is the psychrometric constant $\left(\mathrm{kPa} \mathrm{K}^{-1}\right), \lambda$ is the latent heat of vaporization of water $\left(\mathrm{MJ} \mathrm{kg}^{-1}\right), c_{\mathrm{P}}$ is specific heat per unit mass of air (MJ $\left.\mathrm{kg}^{-1} \mathrm{~K}^{-1}\right), e_{\mathrm{a}}(T a)_{P}$ is vapour density $(\mathrm{kPa})$ at $T a_{\mathrm{P}}$ in the sub-canopy $P, e_{\mathrm{S}}(T s)_{P}$ is vapour density $(\mathrm{kPa})$ at $T s_{P}$ in the sub-canopy $P, R_{a} W_{p}$ is leaf boundary layer resistance for water vapor transport in the sub-canopy $P\left(\mathrm{~s} \mathrm{~m}^{-1}\right)$ and $R_{t p}$ is stomatal resistance in the sub-canopy $P\left(\mathrm{~s} \mathrm{~m}^{-1}\right)$.

A linear relationship between exchangeable water storage and leaf water potential is employed after Federer, (1979); Kowalik and Eckersten, (1984); Eckersten, (1991) and Cienciala et al. (1994), as follows:

$$
V_{P}=\left(\psi_{L_{P}}-\psi_{L \min }\right)\left(\frac{V_{\max _{P}}}{\psi_{L_{\max }}-\psi_{L_{\min }}}\right)
$$

where $\Psi_{\text {Lmin }}$ is minimum leaf water potential $\left(\mathrm{J} \mathrm{kg}^{-1}\right), \Psi_{\mathrm{Lmax}}$ is maximum leaf water potential $\left(\mathrm{J} \mathrm{kg}^{-1}\right)$ and $V_{\max }$ is maximum easily-exchangeable water. A linear relationship between $\Psi_{\mathrm{L}}$ and exchangeable water storage in the canopy was also suggested by Tyree (1988) from experimental data taken from Brough et al. (1986). The idea of a minimum leaf water potential originated from Cowan (1965), who called it the 'supply function'. Jarvis (1975) suggested that the threshold leaf water potential equates to minimum stomatal resistance until the onset of leaf water stress. The leaf water potential is not uniform throughout the tree (Landsberg and McMurtrie, 1984). $\Psi_{\text {Lp }}$ can be calculated from equation 16, provided that $V_{p}$ is calculated in an iteration. As stated earlier, it is considered that water in the tree is assumed to be in storages in each sub-canopy $P$, and thus, the variation of leaf water potential within the sub-canopy can be predicted.

\section{Further research}

The soil-tree-atmosphere water relations consists of important physiological and physical processes which control the soil water dynamics, water uptake by roots, energy and water transfer from the canopy. The following issues have identified for further advancement in the soil-tree-atmospheric water relations.

1. The resulting increase in humidity from soil evaporation can be added to the canopy processes in at least the lower part of the canopy.

2. The trade-off between small and large sub-canopies is that large sub-canopies can affect the accuracy while small sub-canopies can increase the model computational time 
considerably. The optimum size of the sub-canopies can only be found by trial and error and requires further investigation.

3. The assumption of a horizontally-homogeneous, but vertically-heterogeneous canopy has not escaped severe criticism. To have an accurate radiation environment in the crown, the radial distribution of leaf area may be introduced in the canopy.

4. In air temperature calculations, the turbulent parcel of air is trapped in the canopy for some period of time, and then is ejected after being modified by canopy-atmosphere transfer may be shown to be unrealistic. Even though this may give some plausible results, a realistic mechanism needs to be developed.

5. A uniform profile of relative humidity is assumed which may not be realistic. In order to be compatible with other canopy processes in a vigorous three-dimensional canopy, spatial variation of humidity should be incorporated.

6. Precipitation could also be a strong factor for latent heat flux. However, it should be noted that the incorporation of the canopy convective heat flux from free water is essential for acomplete energy balance calculation.

7. Even if a close correlation exists between stomatal aperture and soil moisture (through leaf water potential), the existence of a root signaling process based solely on increased abscisic acid (ABA) in the xylem sap can be postulated.

8. An important question to be answered by future research is how a model can successfully predict transpiration rates over time periods where the physical environment has been subjected to frequent perturbations.

\section{References}

Abdul-Jabbar, A.S., Lugg, D.G., Sammis, T.W., and Gay, L.W. (1984). A field study of plant resistance to water flow in alfalfa. Agronomy J. 76: 765-769.

Alm, D.M., Cavelier, J., and Nobel, P.S. (1992). A finite element model of radial and axial conductivities for individual roots: Development and validation for two desert succulents. Ann. Bot. 69: 87-92.

Andrieu, B., Ivanov, N., and Boissard, P. (1995). Simulation of light interception from a maize canopy model constructed by stereo plotting. Agric. For. Meteorol. 75: 103119.

Aphalo, P. J., and Jarvis, P. G. (1993). An analysis of Ball's empirical model of stomatal conductance. Ann. Bot (London) 72: 321-327.

Baker, J.M. (1996). Use and abuse of crop simulation models. Agron. J. 88: 689-690.

Baldocchi, D.D. (1992). A Langrangian walk model for simulating water vapour, carbon dioxide, and sensible heat flux densities and scalar profiles over and within a soybean canopy. Boundary Layer Meteorol. 61: 113-144.

Baldocchi, D.D. (1993). Scaling water vapour and carbon dioxide exchange from leaves to a canopy: Rules and tools. In: J.R. Ehleringer, and C.B. Field, (Eds.) Scaling Physiological Processes-Leaf to Globe. Academic Press, London, pp. 77-108.

Baldocchi, D.D. (1994). An analytical solution for coupled leaf photosynthesis and stomatal conductance models. Tree Physiol. 14: 1069-1079.

Baldocchi, D.D., Hicks, B.B., and Camara, P. (1987). A canopy stomatal resistance model for gaseous deposition to vegetated surfaces. Atmos. Environ. 21: 91-101. 
Baldocchi, D.D., Luxmoore, R.J., and Hatfield, J.L. (1991). Discerning the forest from the trees: an essay on scaling canopy stomatal conductance. Agric. For. Meteorol. 54: 197-226.

Ball, M. C., Woodrow, I.E., and Berry, J. A.(1987). A model predicting stomatal conductance and its contribution to the control of photosynthesis under different environmental conditions. In: I. Biggins, (Ed), Progress in Photosynthesis Research. Martinus Nijhoff Publishers, Netherlands, pp. 221-224.

Barkstrom, B. (1981). What time does the sun rise and set? Byte 6: 94-114.

Beadle, C.L., Talbot, H., Jarvis, P.G. (1982). Canopy structure and leaf area index in a mature Scots pine forest. Forestry 55:105-123.

Bernston, G.M. (1994). Modelling root architecture: Are there tradeoffs between efficiency and potential of resource acquisition? New Phytol. 127: 483-493.

Bernston, G.M., Lynch, J.P., and Snapp, S. (1995). Fractal geometry and plant root systems: Current perspectives and future applications. In: P. Baveye, J.Y. Parlange, and B.A. Stewart, (Eds.), Fractals of Soil Science. Lewis Publishers, New York, pp.123-154.

Biging, G.S., and Wensel, L.C. (1990). Estimation of crown form for six conifer species of northern California. Can. J. For. Res. 20: 1137-1142.

Biging, G.S., Dobbertin, M. (1995). Evaluation of competition indices in individual-tree growth models. For. Sci. 41: 360-377.

Bossel, H., and Krieger, H. (1994). Simulation of multi-species tropical forest dynamics using a vertically and horizontally structured model. For. Ecol. Manage. 69: 123-144.

Bourgeron, P.S. (1983). Spatial aspects of vegetation structure. In: F.B. Golley (Ed.), Tropical Rain Forest Ecosystems: Structure and Function. Elsevier, Amsterdam, pp. 29-47.

Boyer, J.S. (1985). Water transport. Annual Review of Plant Physiol. 36: 473-516.

Bresler, E. (1991). Soil spatial variability. In: Hanks, J., and Ritchie, J.T. (Eds.), Modelling Plant and Soil Systems. Agronomy Monograph 31, pp. 145-179.

Bristow, K.L., Campbell, G.S., and Calissendorff, C. (1986). The effects of texture on the resistance to water movement within the rhizosphere. Soil Sci. Soc. Am. J. 48: 226270.

Bristow, K.L., Campbell, G.S., and Saxton, K.E. (1985). An equation for separating daily solar irradiation into direct and diffuse components. Agric. For. Meteorol. 35: 123-131.

Broadbridge, P., and White, I. (1988). Constant rate rainfall infiltration: A versatile nonlinear model. I. Analytical solution. Water Resource Res. 24: 145-154.

Brough, D.W., Jones, H.G., Grace, J. (1986). Diurnal changes in water content of the stems of apple trees, as influenced by irrigation. Plant Cell Environ. 9: 1-7.

Brown, S., Gillespie, A.J.R., and Lugo, A.E. (1989). Biomass estimation procedures for tropical forests with applications to forest inventory data. For. Sci. 35: 889-902.

Brutsaert, W. (1982). Evaporation into the Atmosphere: Theory, History, and Applications. Reidel, Dordrecht, The Netherlands, 299 pp.

Campbell, G.S. (1977). An Introduction to Environmental Biophysics. Springer, New York, 245 pp.

Campbell, G.S. (1985). Soil Physics with BASIC: Transport Models for Soil-plant Systems. Elsevier, Amsterdam, 213 pp. 
Campbell, G.S. (1990). Derivation of an angle density function for canopies with ellipsoidal leaf angle distributions. Agric. For. Meteorol. 49: 173-176.

Campbell, G.S. (1991). Simulation of water uptake by plant roots. In: J. Hanks and J.T Ritchie (Eds.), Modelling Plant and Soil Systems. No. 31, Agronomy series. ASA, CSSA, SSSA pp.273-286.

Campbell, G.S., and Norman, J.M. (1989). The description and measurement of plant canopy structure. In: G. Russell, B. Marshall, and P.G Jarvis (Eds.), Plant Canopies: Their Growth, Form, and Function. Cambridge University Press, Cambridge, pp. 1-19.

Cannel, M.G.R., Milne, R., Sheppard, L.J., and Unsworth, M.H. (1987). Radiation interception and productivity of willow. J. Appl. Ecol. 24: 261-278.

Castro, F.D., and Fetcher, N. (1998). Three dimensional model of the interception of light by a canopy. Agric. For. Meteorol. 90: 215-233.

Charles-Edwards, D.A., and Thorpe, M.R. (1976). Interception of diffuse and direct beam radiation by a hedgerow apple orchard. Ann. Bot. 40: 603-613.

Cienciala, E., Eckersten, H., Lindroth, A., and Hallgren, J. (1994). Simulated and measured water uptake by Picea abies under non-limiting soil water conditions. Agric. For. Meteorol. 71: 147-164.

Claasen, N., and Barber, S.A. (1974). A method for characterizing the relation between nutrient concentration and flux into roots of intact plants. Plant Physiol. 54: 564568.

Clemente, R.S., De Jong, R., Hayhoe, H. N., Reynolds, W. D., and Hares, M. (1994). Testing and comparison of three unsaturated soil water flow models. Agric. Water Manage. 25: $135-152$.

Coupland, R. T., Johnson, R. E. 1965 Rooting characteristics of native grassland species in Saskatchewan. Journal of Ecology 53, 475-507.

Dalla-Tea, F. and Jokela, E. J. (1991). Needlefall, canopy light interception, and productivity of young intensively managed slash pine stands. For. Sci. 37: 1298-1313.

De Wit, C.T (1965). Photosynthesis of Leaf Canopies. Agric. Res. Rep. 663. Institute of Biological and Chemical Research on Field Crops and Herbage, Wageningen, pp. 157.

De Wit, C.T., Goudriaan, J., and van Laar, H.H. (1978). Simulation, Respiration and Transpiration of Crops. Pudoc, Wageningen, The Netherlands, $342 \mathrm{pp}$.

Denmead, O.T., and Bradley, E.F. (1985). Flux-gradient relationships in a forest canopy. In: B.A. Hutchison, and B.B. Hicks (Eds.), Forest-atmosphere Interactions. Reidel, Dordrecht, The Netherlands, pp. 421-442.

Dickinson, R.E. (1984). Modelling evapotranspiration for three-dimensional global climate models. Geophys. Monogr. 29: 58-72.

Dogniaux, R. (1977). Computer procedure for accurate calculation for radiation data related to solar energy utilization. Proceedings of the UNESCO/WMO Symposium on Solar Energy, 30 Aug.-3 Sept. 1976, Geneva (WMO No. 477), pp. 191-197.

Eckersten, H. (1991). Simulation model for transpiration, evaporation and growth of plant communities: SPAC-GROWTH Model Description. Division of Agricultural Hydro-technics, Report 164, Dept. of Soil Sci., Swed. Univ. of Agric. Sci., Uppsala, 24 pp. 
Feddes R.A., Kowalik, P.J., and Zaradry, H., (1978). Simulation of Field Water Use and Crop Yield. Centre for Agricultural Publishing and Documentation, Wageningen, 298 pp.

Feddes, R.A., Bresler, E., Neuman, S.P. (1974). Field test of a modified numerical model for water uptake by root systems. Water Resour. Res. 10: 1199-1206.

Fernandez, C.J. (1992). Simulation of normal annual and diurnal temperature oscillations in non-mountainous mainland United States. Agron. J. 84: 244-251.

Finnigan, J.J., and Raupach, M.R. (1987). Modern theory of transfer in plant canopies in relation to stomatal characteristics. In: Zeiger, E., Farquhar, G., and Cowan, I. (Eds.), Stomatal Function. Stanford Uni. Press, pp. 385-429.

Fisher, J.B. (1992). How predictive are computer simulations of tree architecture?. Int. J. Plant Sci. 153: 137-146.

Fisher, M.J., Charles-Edwards, D.A., and Ludlow, M.M. (1981). An analysis of the effects of repeated short-term soil water deficits on stomatal conductance to carbon dioxide and leaf photosynthesis by the legume Macroptilium atropurpureum cv, Siratro. Aust. J. Plant Physiol. 8: 347-357.

Fitter, A.H. (1987). An architectural approach to the comparative ecology of plant root systems. New Phytol. 106: 61-77.

Frensch, J., and Steudle, E. (1989). Axial and radial hydraulic resistance to roots of maize (Zea mays L.). Plant Physiol. 91: 719-726.

Friend, A.D. (1995). PGEN: an integrated model of leaf photosynthesis, transpiration, and conductance. Ecol. Model. 77: 233-255.

Gates, D.M. (1962). Energy Exchange in the Biosphere. Harper and Row, New York, 445 pp.

Gates, D.M. (1980). Biophysical Ecology. Springer-Verlag, New York, 611 pp.

Gholz, H.L., Vogel, S.A., Cropper, W.P. Jr., Mckelvey, K., Ewel, K.C., Teskey, R.O., and Curran, P.J. (1991). Dynamics of canopy structure and light interception in Pinus elliottii stands, north Florida. Ecol. Monogr. 61: 33-51.

Gijzen, H., and Goudriaan, J. (1989). A flexible and explanatory model of light distribution and photosynthesis in row crops. Agric. For. Meteorol. 48: 1-20.

Givnish, T.J. (1984). Leaf and canopy adaptations in tropical forests. In: E. Medina, H.A. Mooney, and C. Vazquez-Yanes (Eds.), Physiological Ecology of Plants of the Wet Tropics. DrW. Junk Publishers, The Hague, pp. 51-84.

Goel, N.S., 1988. Models of vegetation canopy reflectance and their use in estimation of biophysical parameters from reflectance data. Remote Sensing Reviews 4: 1-212.

Goudriaan, J. (1977). Crop micro-meteorology: a simulation study. Simulation monographs, Pudoc, Wageningen, 249 pp.

Goudriaan, J. 1988. The bare bones of leaf angle distribution in radiation models for canopy photosynthesis and energy exchange. Agric. Forest. Meteorol. 43: 155-169.

Goudriaan, J., and van Laar, H.H. (1994). Modelling Potential Crop Growth Processes: Textbook with Exercises. Kluwer Academic Press. The Netherlands, 239 pp.

Grace, J. (1983). Outline Studies in Ecology: Plant-atmospheric Relations. Chapman and Hall, London, 92 pp.

Grace, J.C., Jarvis, P.G., and Norman, J.M. (1987). Modelling the interception of solar radiant energy in intensively managed stands. N. Z. J. For. Sci. 17: 193-209. 
Gray, H.L. (1978). The vertical distribution of needles and branch-wood in thinned and unthinned 80-year-old lodgepole pine. Northwest Sci. 52: 303-309.

Gutschick, V.P., and Weigel, F.W. (1988). Optimizing the canopy photosynthetic rate by patterns of investment in specific leaf mass. Am. Nat. 132: 67-86.

Hagihara, A., and Hozumi, K. (1986). An estimate of the photosynthetic production of individual trees in a Chamaecyparis obtusa plantation. Tree Physiol. 1: 9-20.

Hall, A.E. (1982). Mathematical models of plant water loss and plant water relations. In: Lang, O.L., Nobel, P.S., Osmand, C.B., and Ziegler, H.(Eds.), Physiological Plant Ecology II, Encyclopaedia of Plant Physiology. Vol.12B. Springer-Verlag, Berlin, pp. 231-261.

Halle, F., Oldemann, R.A.A., Tomlinson, P.B. (1978). Tropical Trees and Forests: An Architectural Analysis. Springer, The Netherlands, 345 pp.

Hassika, P., Berbigier, P., and Bonnefond, J.M. (1997). Measurement and modelling of the photosynthetically active radiation transmitted in a canopy of maritime pine. Annales des Sciences Forestieres Paris 54: 715-730.

He, J., Chee, C.W., and Goh, C.J. (1996). Photoinhibition of Heliconia under natural tropical conditions: The importance of leaf orientation for light interception and leaf temperature. Plant Cell Environ. 19: 1238-1248.

Hetrick, B.A. (1988). Physiological and topological assessment of effects of a vesiculararbuscular mycorrhizal fungus on root architecture of big bluestem. New Phytol. 110: 85-96.

Horn, H.S. (1971). The Adaptive Geometry of Trees. Princeton University Press. New Jersey, $342 \mathrm{pp}$.

Huber, B. (1924). Die Beurteilung des Wasserhaushalts der Pflanze. Ein Beitrag zur vergleichenden Physiologie. Jahrb. Wiss. Bot. 24: 1-120.

Jackson, J.E., and Palmer, J.W. (1972). Interception of light by model hedgerow orchards in relation to latitude, time of year and hedgerow configuration and orientation. J. Appl. Ecol. 9: 341-357.

Jahnke, L.S., and Lawrence, D.B. (1965). Influence of photosynthetic crown structure on potential productivity of vegetation, based on primarily on mathematical models. Ecol. 46: 319-326.

Janz, T.C., Stonier, R.J. (1995). Modeling water flow in cropped soils: Water uptake by plant roots. Environment International 21: 704-709.

Jarvis, P.G. (1975). Water transfer in plants. In: D.A. de Vries and N.H. Afgan (Eds.), Heat and Mass Transfer in the Biosphere. 1. Transfer Processes in Plant Communities. Halsted, Washington, D.C., pp. 369-394.

Jarvis, P.G. (1976). The interpretation of the variations in leaf water potential and stomatal conductance found in canopies in the field. Philos. Trans. R. Soc. London. Ser. B. 273: 593-610.

Jarvis, P.G. (1995). Scaling processes and problems. Plant Cell Environ. 18: 1079-1089.

Jarvis, P.G., and Leverenz, J.W. (1983). Productivity of temperature, deciduous, and evergreen forests. In: O. Lange, P. Nobel, C. Osmand and H. Ziegler (Eds.), Physiological Plant Ecology IV. Ecosystem Processes: Mineral Cycling, Productivity and Man's Influence. Springer, New York, pp. 233-280. 
Jarvis, P.G., Edwards, W.R.N., and Talbot, H. (1981). Models of plant and crop water use. In: D.A. Rose and D.A. Charles-Edwards (Eds.), Mathematics of Plant Physiology. Academic Press, London, pp. 151-194.

Jarvis, P.G., Miranda, H.S., and Muetzelfeldt, R.I. (1985). Modelling canopy exchanges of water vapour and carbon dioxide in coniferous forest plantations. In: B.A. Hutchison, and B.B. Hicks (Eds.), Forest Atmosphere Interactions. Reidel, Dordrecht, The Netherlands, pp. 521-542.

Jones, H. G. (1992). Plant Microclimate: A Quantitative Approach to Environmental Plant Physiology (second edition) Cambridge University Press, New York, 428 pp.

Jones, H.G. (1982). Plants and Microclimate. Cambridge University Press, Cambridge, UK, 345 pp.

Kelliher, F.M., Leuning, R., Raupach, M.R. and Schulze, E.D. (1994). Maximum conductances for evaporation from global vegetation types. Agric. For. Meteorol. 73: 1-16.

Kinerson, R.J., Fritchen, L.J. (1971). Modelling a coniferous forest canopy. Agric. Meteorol. 8: 439-445.

Kinerson, R.J., Higginbotham, K.O., and Chapman, R.C. (1974). Dynamics of foliage distribution within a forest canopy. J. Appl. Ecol. 11: 347-353.

Kira, T., Shinozaki, K., and Hozumi, K. (1969). Structure of forest canopies as related to their primary productivity. Plant Cell Physiol. 10: 129-142.

Kira, T., Shinozaki, K., and Hozumi, K. (1969). Structure of forest canopies as related to their primary productivity. Plant Cell Physiol. 10: 129-142.

Kjelgren, R., and Montague, T. (1998). Urban tree transpiration over turf and asphalt surfaces. Atmospheric Environ. 32: 35-41.

Kock, B., Ammer, U., Schneider, T., and Wittmeir, H. (1990). Spectroradiometer measurements in the laboratory and in the field to analyse the influence of different damage symptoms on the reflection spectra of forest trees. Int. J. Remote Sens. 11: $1145-1163$.

Kodrik, M. (1995). Distribution and fractional composition of below ground spruce biomass and length in Biosphere Reserve Pol'ana Ekologia (Bratislava) 14: 413-417.

Kohyama, T. (1991). A functional model describing sapling growth under a tropical forest canopy. Functional Ecol. 5: 83-90.

Kowalik, P.J., and Eckersten, H. (1984). Water transfer from soil through plants to the atmosphere in Willow energy forest. Ecol. Model.. 26: 251-284.

Krasilnikov, P.K. (1968). On the classification of the root systems of trees and shrubs. In: Methods of Productivity Studies in Root Systems and Rhizophore Organisms. USSR Academy of Sciences, NAUKA, Leningrad, pp. 101-114.

Kriebel, K.T. (1978). Measured spectral bidirectional reflection properties of four vegetated surfaces. Appl. Optics 17: 253-259.

Landsberg, J.J. (1986). Physiological Ecology of Forest Production. Academic Press, London, 191 pp.

Landsberg, J.J. and Fowkes, N.D. (1978). Water movements through plant roots. Ann. Bot. 42: 493-508.

Landsberg, J.J., and James, G.B. (1971). Wind profiles in plant canopies: studies on an analytical model. J. Appl. Ecol. 8: 729-741. 
Landsberg, J.J., and McMurtrie, R. (1984). Water use by isolated trees. Agric. Water Manage. 8: $223-242$.

Lang, A.R.G. (1986). Leaf area and average leaf angle from transmission of direct sunlight. Aust. J. Bot. 34: 349-355.

Law, B.E., Cescatti, A., and Baldocchi, D.D. (2000). Leaf area distribution and radiative transfer in open-canopy forests: implications for mass and energy exchange. Tree Physiology, 21 (12-13): 777-787.

Lemeur, R. (1973). A method for simulating the direct solar radiation regime in Sunflower, Jerusalem artichoke, Corn, and Soyabean canopies using actual stand structure data. Agric. Meteorol. 12: 229-247.

Leuning, R. (1995). A critical appraisal of a combined stomatal-photosynthesis model for $\mathrm{C}_{3}$ species. Plant Cell and Environ. 18: 339-355.

Leuning, R., Kelliher, F.M., dePury, D. and Schulze, E.D. (1995). Leaf nitrogen, photosysthesis, conductance and transpiration: scaling from leaves to canopies. Plant Cell and Environ. 18: 1129-1146.

Liu, B.Y., and Jordan, R.C. (1960). The interrelationship and characteristic distribution of direct, diffuse and total solar radiation. Solar Energy 4: 1-19.

Lohammar, T., Larrsson, S., Linder, S., and Falk, S.O., (1980). FAST simulation models of gaseous exchange in Scots pine. In: T. Persson (ed), Structure and Function of Northern Coniferous Forets - An Ecosystem Study. Ecol. Bull. 32: 505-523.

Lungley, D.R. (1973). The growth of root systems: A numerical computer simulation model. Plant Soil 38: 145-159.

Lynn, B., and Carlson, T.N. (1990). A model illustrating plant versus external control of transpiration. Agric. For. Meteorol. 52: 5-43.

Mandelbrot, B.B. (1983). The Fractal Geometry of Nature. Freeman, New York, 468 pp.

Massman, W.J. (1981) Foliage distribution in old-growth coniferous tree canopies. Can. J. For. Res.12:10-17.

McIlroy, I.C. 1984. Terminology and concepts of natural evaporation. Agric. Water Manage. 8: 77-98.

McMurtrie, R.E. (1993). Modelling of canopy carbon and water balance. In: D.O. Hall, J.M.O. Scurlock, H.R. Bolhar-Nordenkamf, R.C. Leegood, and S.P.Long. Photosynthesis and Production in a Changing Environment: A Field and Laboratory Manual. Chapman and Hall, London, 231 pp.

Melchior, W., and Steudle, E. (1993). Water transport in onion roots; Change of axial and radial hydraulic conductivities during root development. Plant Physiol. 101: 13051315.

Meyer, W.S., and Ritchie, J.T. (1980). Resistance to water flow in the sorghum plant. Plant Physiol. 65: 33-39.

Meyers, T.P., and Paw U, K.T. (1986). Testing of a higher-order closure model for modelling airflow within and above plant canopies. Boundary Layer Meteorol. 37: 297-311.

Meyers, Y.P., and Paw U, K.T. (1987). Modelling plant canopy micro-meteorology with higher-order closure principles. Agric. For. Meteorol. 41: 143-163. 
Miyashita, K., and Maitani, T. (1998). Vertical structure of temperatures of tree's leaves and gate wall at Rashomon doline. Bulletin of the Research Institute for Bioresources, Okayama University 5: 169-181.

Mohren, G.M.J. (1987). Simulation of Forest Growth, Applied to Douglas fir Stands in The Netherlands. Pudoc, Wageningen, 213 pp.

Mohren, G.M.J., Van Gerwen, and Spitters, C.J.T. (1984). Simulation of primary production in even-aged stands of Douglas fir. For. Ecol. Manage. 9:27-49.

Moldrup, P., Rolston, D.E., Hansen, J.A.A. and Yamaguchi, T. (1992). A simple mechanistic model for soil resistance to plant water uptake. Soil Sci. 150: 87-93.

Molz, F.J., (1981). Models of water transpiration soil-plant system: A review. Water Resour. Res. 17: 1245-60

Monsi, M., and Saeki, T. (1953). Uber den lichtfaktor in den pflanzengesellschaften und seine bedeutung fur die stoffproduktion. Jpn. J. Bot. 14: 22-52.

Monteith, J.L. (1965). Light distribution and photosynthesis in field crops. Ann. Bot. 29: 1737.

Monteith, J.L. (1975). Principles of Environmental Physics. Edward Arnold, London, 241 pp.

Monteith, J.L. (1980). The development and extension of Penman's evaporation formula. In: D. Hillel (Ed.), Application of Soil Physics. Academic Press, New York, pp. 247-253.

Monteith, J.L., and Unsworth, M.H. (1990). Principles of Environmental Physics. Edward Arnold, 291 pp.

Morales, D., Jiménez, M.S., González-Rodriguez, A.M., and _ermák, J. (1996). Laurel forests in Tenerife, canary Islands: II. Leaf distribution patterns in individual trees. Trees 11: 41-46.

Myneni, R. B., Gutschick, V. P., Asrar, G., and Kanemasu, E.T. 1988. Photon transport in vegetation canopies with anisotropic scattering - part I. Scattering phase functions in one angle. Agric. For. Meteorol. 42: 1-16.

Myneni, R.B. (1991). Modelling radiative transfer and photosynthesis in three-dimensional vegetation canopies. Agric. For. Meteorol. 55: 323-344.

Myneni, R.B., and Impens, I. (1985). A procedural approach for studying the radiation regime of infinite and truncated foliage spaces. 1. Theoretical considerations. Agric. For. Meteorol. 34: 3-16.

Myneni, R.B., and Ross, J. (1990). Photon-vegetation Interactions. Applications in Optical Remote Sensing and Plant Ecology. Springer-Verlag, Berlin, 565 pp.

Myneni, R.B., Asrar, G., and Gerstl, A.W. (1990). Radiative transfer in three dimensional leaf canopies. Transport Theory Stat. Phys. 19: 205-250.

Myneni, R.B., Ross, J., and Asrar, G. 1989. A review on the theory of photon transport in leaf canopies. Agric. For. Meteorol. 45: 1-153.

Neumann, E.L., Thurtell, G.W., and Stevenson, K.R. (1974). In situ measurements of leaf water potential and resistance to water flow in corn, soybean and sunflower at several transpiration rates. Can. J. Plant Sci. 54: 175-184.

Newman, E.I. (1976). Water movement through root systems. Phil. Trans. R. Soc. B. 273: 467478. 
Nikinmaa, E. (1992). Analysis of the growth of Scots pine: Matching structure with function. Acta For. Fenn. 235: 68-88.

Nikolov, N.T., and Zeller, K.F. (1992). A solar radiation algorithm for ecosystem dynamic models. Ecol. Model. 61: 149-168.

Nikolov, N.T., Massman, W.J., and Schoettle, A.W. (1995). Coupling biochemical and biophysical pressures at the leaf level: an equilibrium photosynthesis model for leaves of $\mathrm{C}_{3}$ plants. Ecol. Model. 80: 205-235.

Nobel, P.S. and Alm, D.M. (1993). Root orientation vs. water uptake simulated for monocotyledonous and dicotyledonous desert succulents by a root-segment model. Functional Ecology 7: 600-609.

North, G.B., and Nobel, P.S. (1995). Hydraulic conductivity of concentric root tissues of Agave deserti Engelm. under wet and drying conditions. New Phytologist 130: 4757.

Oker-Blom, P. (1986). Photosynthetic radiation regime and canopy structure in modelled forest stands. Acta For. Fenn. 197: 44-58.

Oker-Blom, P., and Kellomaki, S. (1983). Effect of grouping of foliage on the within-stand and within-crown light regime: comparison of random and grouping canopy models. Agric. For. Meteorol. 28: 143-155.

Otterman, J., Novak, M.D., and Starr, D.O.C. (1993). Turbulent heat transfer from a sparsely vegetated surface: two component representation. Boundary Layer Meteorol. 64: 409-420.

Palmer, J.W. (1977). Diurnal light interception and computer model of light interception by hedgerow apple orchards. J. Appl. Ecol. 14: 601-614.

Passioura, J.B. (1972). Effects of root geometry on the yield of wheat growing on stored water. Aust. J. Agric. Res. 23: 745-752.

Passioura, J.B. (1984). Hydraulic resistance of plants. I. Constant or variable? Aust. J. Plant Physiol. 11: 333-339.

Passioura, J.B. (1988). Water transport in and to roots. Annual Review of Plant Physiology and Plant Molecular Biology 39: 245-256.

Paw U, K.T. and Meyers, T.P. (1989). Investigations with higher order canopy turbulence model into mean source-sink levels and bulk canopy resistances. Agric. For. Meteorol. 47: 259-271.

Paw U, K.T., Qie, J., Su, H.B., Watanabe, T., and Brunet, Y. (1995). Surface renewal analysis: a new method to obtain scalar fluxes. Agric. For. Meteorol. 74: 119-137.

Perelyot, N.A. (1970). Trudy Ukrainskogo nauchno-issleedovatelskogo gidrometeorologicheskogo instituta (Proc. Ukrainian Inst. Hydrometeorol.) 94: 46-51.

Philip, J.R. (1966). Plant water relations: Some physical aspects. Ann. Rev. Pl. Physiol. 17: 245-268.

Pinker, R.T., Thompson, O.E., and Eck, T.F. (1980). The albedo of a tropical evergreen forest. Q.J.R. Meteorol. Soc. 106: 551-558.

Pregitxer, K.S., Kubiske, M.E., Yu, C.K., and Hendrick, R.L. (1997). Relationships among root branch order, carbon, and nitrogen in four temperate species. Oecologia 111: 302-308. 
Pukkala, T., Beaker, P., Kuuluvainen, T., and Oker-Blom, P. (1991). Predicting spatial distribution of direct radiation below forest canopies. Agric. For. Meteorol. 55: 295307.

Pukkala, T., Kuuluvainen, T., and Stenberg, P. (1993). Below-canopy distribution of photosynthetically active radiation and its relation to seeding growth in a boreal Pinus sylvestris stand: A simulation approach. Scand. J. For. Res. 8: 313-325.

Ranatunga, Kemachandra, Nation, E.R., Barratt, D.G. (2008) Review of soil water models and their applications in Australia Environmental Modelling \& Software, Volume 23, Issue 9, Pages 1182-1206

Ranatunga, Kemachandra., and Murty, V.V.N. (1992). Modelling irrigation deliveries for tertiary units in large irrigation systems. Agric. Water Manage. 21: 197-214.

Raupach, M.R. (1989). Canopy transport processes. In: W.L. Steffen and O.T. Denmead (Eds.), Flow and Transport in the Natural Environment: Advances and applications. Springer-Verlag, Berlin, pp. 1-33.

Raupach, M.R. (1991). Vegetation-atmosphere interaction in homogeneous and heterogeneous terrain: some implications of mixed-layer dynamics. In: A. Henderson-Sellers and A.J. Pitman (Eds.), Vegetation and Climatic Interactions in Semi-arid Regions. Kluwer Academic Publishers, The Netherlands, pp. 105-120.

Raupach, M.R. (1995). Vegetation-atmosphere interaction and surface conductance at leaf, canopy and regional scales: discussion. Aust. J. Plant Physiol. 15: 705-716.

Raupach, M.R., and Finnigan, J.J. (1988). Single-layer models of evaporation from plant canopies are incorrect but useful, whereas multilayer models are correct but useless: Discuss. Aust. J. Plant Physiol. 15: 705-716.

Richards, L.A. (1931). Capillary conductivity of liquid through porous media. Physics 1: 318333.

Richards, P.W. (1983). The tree-dimensional structure of tropical rain forest. In: S.L. Sutton, T.C. Whitmore, and A.C. Chadwick (Eds.), Tropical rain forest: Ecology and Management. Blackwell, Oxford, pp. 3-10.

Robinson, D., Linehan, D.J., and Caul, P. (1991). What limits nitrate uptake from soil? Plant Cell Environ. 14: 77-85.

Ross, J. (1975). Radiative transfer in plant communities. In: J.L. Monteith (Ed.), Vegetation and the Atmosphere, Vol. 1: Principles. Academic Press, New York, pp. 332-365.

Ross, J., (1981). The Radiation Regime and Architecture of Plant Stands. Dr. W. Junk Publishers, The Hague, The Netherlands, pp 391-443.

Rotenberg, E., Mamane, Y., Joseph, J.H. (1999). Long wave radiation regime in vegetationparameterisations for climate research Environmental Modelling \& Software 13 (34), 361-371.

Running, S.W., and Coughlan, J.C. (1988). A general model for forest ecosystem processes for regional applications. 1. Hydrologic balance, canopy gas exchange and primary production processes. Ecol. Model. 42: 125-154.

Ryel, R.J., Beyschlag, W., and Caldwell, M.M. (1993). Foliage orientation and carbon gain in two tussock grasses as assessed with a new whole-plant gas-exchange model. Functional Ecology 7: 115-124.

Salby, M.L. (1996). Fundamentals of Atmospheric Physics. Academic Press, London, 627 pp. 
Santantonio, D., Hermann, R.K. and Overton, W.S. (1977). Root biomass studies in forest ecosystems. Pedobiologia 17: 1-31.

Sattelmacher, B., Gerendas, J., Thoms, K., Bruck, H., and Bagdady, N.H. (1990). Interaction between root growth and mineral nutrition. Environ. Exp. Bot. 33: 63-73.

Saugier, B. (1996). The evapotranspiration of grasslands and crops. Comptes Rendus de l'Academie d'Agriculture de France 82: 133-153.

Schreuder, H.T., Swank, W.T. (1974). Coniferous stands characterized with the Weibull distribution. Can. J. For. Res. 4: 518-523.

Sellers, P.J., 1985. Canopy reflectance, photosynthesis and transpiration. Int. J. Remote Sen. 8:1335-1372.

Shibusawa, S. (1994). Modelling the branching growth fractal pattern of the maize root system. Plant Soil 165: 339-347.

Shinozaki, K., Yoda, K., Orava, P.J., and Kira, T. (1964). A quantitative analysis of plant form-the pipe model theory. 1. Basic analysis, Jap. J. Ecol. 14: 97-105.

Sinoquet, H., and Bonhomme, R. (1992). Modelling radiative transfer in mixed and row intercropping systems. Agric. For. Meteorol. 62: 219-240.

Soumar, A., Groot, J.J.R., Kon_, D., and Radersma, S. (1994). Structure spatiale du systeme racinaire de deux arbres du Sahel: Acacia seyal and Sclerocaryea birrea. Rapport PSS No. 5. Wageningen, $45 \mathrm{pp}$.

St Aubin, G., Canny, M.J., and McCully, M.E. (1986). Living vessel elements in late metaxylem of sheathed maize roots. Ann. Bot. 58: 145-157.

Steudle, E., and Brinckmann, E. (1989). The osmometer model of the root: Water and solute relations of roots of Phaseolus coccineus. Botanica Acta. 102: 85-95.

Stewart, J.B. (1971). The albedo of a pine forest. Q.J.R. Meteorol. Soc. 97: 561-564.

Stewart, J.B. (1988). Modelling surface conductance of pine forest. Agric. For. Meteor. 43: 1935.

Strandman, H., Väisänen, H., Kellomäki, S. (1993). A procedure for generating synthetic weather records in conjunction of climatic scenario for modelling of ecological impacts of changing climate in boreal conditions. Ecol. Model. 70: 195-220.

Tardieu, F. (1988). Analysis of the spatial variability of maize root density: II Distance between roots. Plant Soil 107: 267-272.

Thornley, J.H.M., and Johnson, I.R (1990). Plant and Crop Modelling: A Mathematical Approach to Plant and Crop Physiology. Clarendon Press, Oxford, England, 669 pp.

Tyree, M.T. (1988). A dynamic model for water flow in a single tree: evidence that models must account for hydraulic architecture. Tree Physiol. 4: 195-217.

van Engelen, A.F., and Guerts, H.A.M. (1983). Een Rekenmodel dat het Verloop van de Temperatuur over een Etmaal Berekent uit Drie Termijnmetingen van de Temperatuur. KNMI, De Bilt, The Netherlands, 44 pp.

Van Noordwijk, M., and Brouwer, G. (1995). Roots as sinks and sources of carbon and nutrients in agricultural systems. Advances in Agroecology 23: 234-239.

Van Noordwijk, M., Spek, L.Y., and De Willigen, P. (1994). Proximal root diameters as predictors of total root system size for fractal branching models. 1. Theory. Plant Soil 164: 107-118. 
Waggoner, P.E., and Reifsnyder, W.E. (1968). Simulation of temperature, humidity and evaporation profiles in a leaf canopy. J. Appl. Meteorol. 7: 400-409.

Walker, B. H., and Langridge, J.L. (1996). Modelling plant and soil water dynamics in semi-arid ecosystems with limited site data. Ecol. Model. 87: 153-167.

Wang, Y., and Baldocchi, D.D. (1989). A numerical model for simulating the radiation regime within a deciduous canopy. Agric. For. Meteorol. 46: 313-337.

Wang, Y.P., and Jarvis, P.G. (1990). Description and validation of an array modelMAESTRO. Agric. For. Meteorol. 51: 257-280.

Weatherley, P.E. (1970). Some aspects of water relations. Adv. Bot. Res. 3: 171-186.

Weaver, J.E. (1968). Classification of root systems of forbs of grassland and a consideration of their significance. Ecology 39: 393-401.

Weiss, A., and Norman, J.M. (1985). Partitioning solar radiation into direct and diffuse, visible and near-infrared components. Agric. For. Meteorol. 34: 205-213.

West, P.W., and Wells, K.F. (1992). Method of application of a model to predict the light environment of individual tree crowns and its use in a eucalypt forest. Ecol. Model. 60: 199-231.

White, D.A., Beadle, C.L., Sands, P.J., Worledge, D., and Honeysett, J.L. (1999). Quantifying the effect of cumulative water stress on stomatal conductance of Eucalyptus globulus and Eucalyptus nitens: a phenomenological approach. Aust. J. Plant Physiol. 26: 1727.

Whitehead, D., Grace, J.C., and Godfrey, M.J.S. (1990). Architectural distribution of foliage in individual Pinus radiata D: Crowns and the effects of clumping on radiation interception. Tree Physiol. 7: 135-155.

Williams, M., Rastetter, E.B., Fernades, D.N., Goulden, M.L., Wofsy, S.C., Shaver, G.R., Meillo, J.M., Munger, J.W., Fan, S.M., and Nadelhoffer, K.J. (1996). Modelling thesoil-plant-atmosphere continuum in a Quercus-Acer stand at Harvard forest: the regulation of stomatal conductance by light, nitrogen and soil-plant hydraulic properties. Plant Cell Environ. 19: 911-927.

Worner, S.P. (1988). Evaluation of diurnal temperature models and thermal summation in New Zealand. J. Econ. Entomol. 81: 9-13.

$\mathrm{Wu}, \mathrm{J}$. (1990). Modelling the energy exchange processes between plant communities and environment. Ecol. Model. 51: 233-250.

Yang, S., Liu, X., and Tyree, M.T. (1998) A model of stomatal conductance in sugar maple (Acer saccharum Marsh). J. Theoretical Biol. 191: 197-211.

Yong, X., Miller, D.R, and Montgomery, M.E. (1993). Vertical distribution of canopy foliage and biologically active radiation in a defoliated/defoliated hardwood forest. Agric. For. Meteorol. 67: 129-146.

Zamir, M. 2001. Fractal dimensions and multifractility in vascular branching. J. Theor. Biol. 212: 183-190.

Zeng, X., Decker, M. (2009) Improving the Numerical Solution of Soil Moisture-Based Richards Equation for Land Models with a Deep or Shallow Water Table. J. Hydrometeor, 10, 308-319. 
Zermeno, G.A., Hipps, L.E. (1997). Downwind evolution of surface fluxes over a vegetated surface during local advection of heat and saturation deficit. J. Hydrol. (Amsterdam) 192: 189-210. 


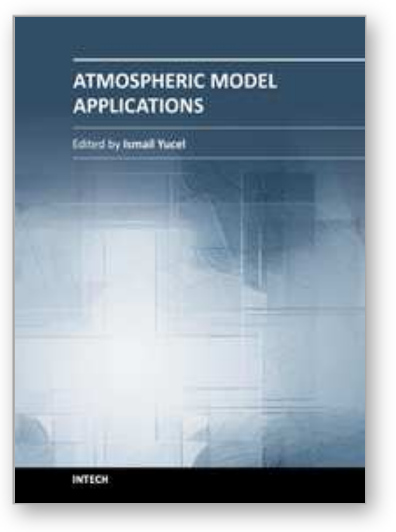

\author{
Atmospheric Model Applications \\ Edited by Dr. Ismail Yucel
}

ISBN 978-953-51-0488-9

Hard cover, 296 pages

Publisher InTech

Published online 04, April, 2012

Published in print edition April, 2012

This book covers comprehensive text and reference work on atmospheric models for methods of numerical modeling and important related areas of data assimilation and predictability. It incorporates various aspects of environmental computer modeling including an historical overview of the subject, approximations to land surface and atmospheric physics and dynamics, radiative transfer and applications in satellite remote sensing, and data assimilation. With individual chapters authored by eminent professionals in their respective topics, Advanced Topics in application of atmospheric models try to provide in-depth guidance on some of the key applied in atmospheric models for scientists and modelers.

\title{
How to reference
}

In order to correctly reference this scholarly work, feel free to copy and paste the following:

Kemachandra Ranatunga (2012). Soil-Tree-Atmosphere Water Relations, Atmospheric Model Applications, Dr. Ismail Yucel (Ed.), ISBN: 978-953-51-0488-9, InTech, Available from:

http://www.intechopen.com/books/atmospheric-model-applications/soil-tree-atmosphere-water-relations

\section{INTECH}

open science | open minds

\section{InTech Europe}

University Campus STeP Ri

Slavka Krautzeka 83/A

51000 Rijeka, Croatia

Phone: +385 (51) 770447

Fax: +385 (51) 686166

www.intechopen.com

\section{InTech China}

Unit 405, Office Block, Hotel Equatorial Shanghai

No.65, Yan An Road (West), Shanghai, 200040, China

中国上海市延安西路65号上海国际贵都大饭店办公楼 405 单元

Phone: +86-21-62489820

Fax: +86-21-62489821 
(C) 2012 The Author(s). Licensee IntechOpen. This is an open access article distributed under the terms of the Creative Commons Attribution 3.0 License, which permits unrestricted use, distribution, and reproduction in any medium, provided the original work is properly cited. 